\title{
AMMOLITE: IRIDESCENT FOSSILIZED AMMONITE FROM SOUTHERN Alberta, CANADA
}

By Keith A. Mychaluk, Alfred A. Levinson, and Russell L. Hall

\begin{abstract}
A relative newcomer to the world gem market (since the 1960s), Ammolite is a form of aragonite that is obtained from vivid iridescent fossilized ammonite shells mined in Alberta, Canada. The gem material, from the extinct species Placenticeras meeki and $\mathrm{P}$. intercalare, is found only in certain horizons of the Bearpaw Formation of Late Cretaceous age (about 70-75 million years old). Because the iridescent layer is generally thin and fragile, most Ammolite is fashioned into assembled stones. This article describes the history of Ammolite as a gem material and the geologic setting of the main producing mines; offers an explanation for the formation of Ammolite and the origin of its color (i.e., iridescence caused by an interference phenomenon); presents production data, gemological properties, and a grading classification; and describes the manufacturing process.
\end{abstract}

mmolite is one of the few new natural gem materials to enter the marketplace in the last 50 years (figure 1). Like tanzanite and sugilite-which were introduced to the trade in 1967 and 1980, respectively-Ammolite occurs in sufficient quantities to be economically significant. Ammolite is a trade name for the iridescent, nacreous layer of the shell of specific fossil ammonites (figure 2) found in the Bearpaw Formation of Late Cretaceous age (figure 3). Commercial quantities of gem-quality Ammolite have been reported only from southern Alberta and only from the two ammonite species Placenticeras meeki and P. intercalare. Ammonite is a paleontologic term applied to a group of extinct marine cephalopods (squid-like organisms with disk-shaped coiled shells that are divided internally into chambers) that were particularly abundant during the Jurassic and Cretaceous periods (about 200-65 million years ago).

Ammolite has similarities to some modern shells such as abalone and paua, but the only fossil shell that resembles Ammolite with respect to play of color is lumachelle (Sinkankas, 1997), the iridescent fossiliferous marble that is best known from the lead mines at Bleiberg, Austria (Niedermayr, 1994). However, any similarities between Ammolite and other iridescent shell materials are superficial. Although the iridescence of lumachelle is associated with an ammonite, specifically Carnites floridus, this species is significantly older (Late Triassic in age) than those that give rise to Ammolite, and the two materials have different geologic occurrences. Further, lumachelle differs from Ammolite in appearance (e.g., most Ammolite has a characteristic fracture pattern). The former has been used primarily for nonjewelry purposes (i.e., as an ornamental stone) and, according to some who have seen the two materials (e.g., Sinkankas, 1976; Pough, 1986), Ammolite has superior iridescence.

Ammolite layers are typically thin $0.5-8 \mathrm{~mm}$ before polishing and 0.1-3 $\mathrm{mm}$ after polishing). They are composed predominantly of soft aragonite $\left(3^{1} / 2-4\right.$ on the Mohs scale), yet they are sufficiently thick and

\footnotetext{
See end of article for About the Authors information and acknowledgments. Gems \& Gemologr, Vol. 37, No. 1, pp. 4-25

(C) 2001 Gemological Institute of America
} 


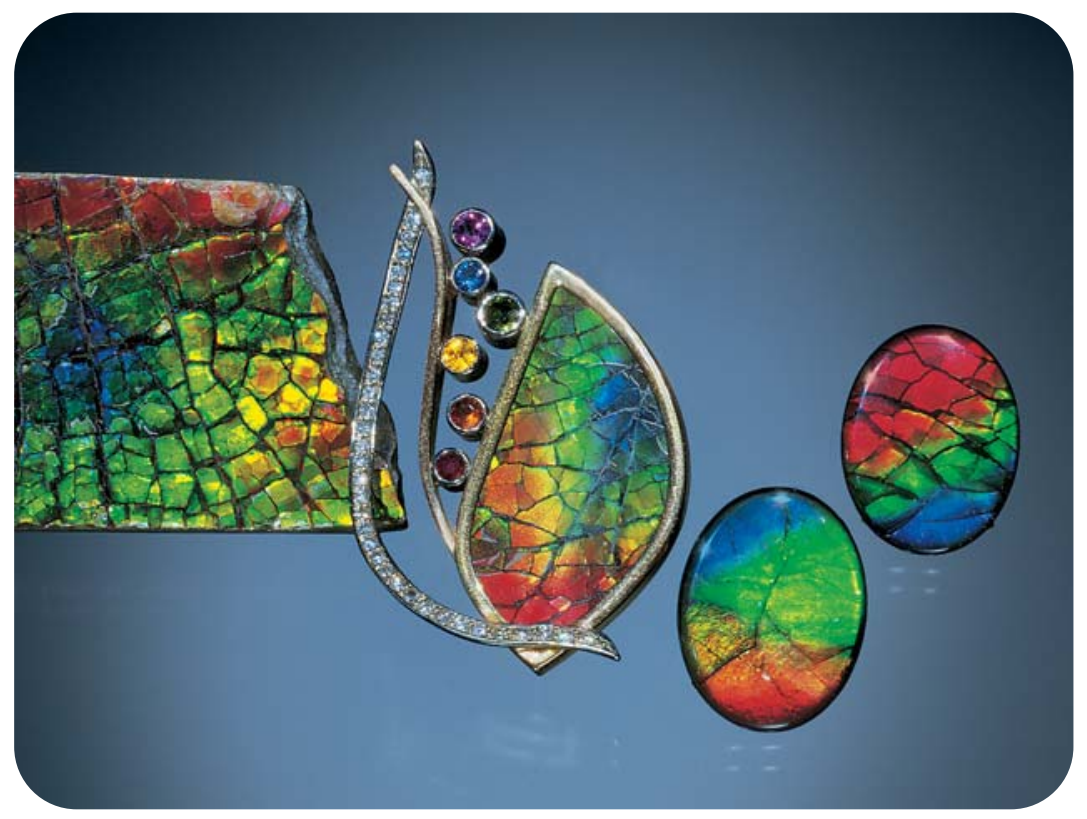

Figure 1. These Ammolites are from the St. Mary River area, Alberta, Canada. The rough specimen $(3 \times 4 \mathrm{~cm})$ is typical of the high-quality Ammolite seen on the market today. Note the numerous iridescent color panes (i.e., flat areas of uniform color) that are separated by thin "healed" fractures. The two loose stones are Ammolite triplets (each $1.5 \times 2.0 \mathrm{~cm})$; the one on the left is made with type 2 sheet Ammolite, and the other with the more common type 1 fractured Ammolite. The brooch, by Llyn Strelau of Jewels By Design (Calgary), contains a $17.85 \mathrm{ct}$ one-sided solid Ammolite set in $18 \mathrm{~K}$ gold with ruby, fire opal, yellow sapphire, chrome tourmaline, blue sapphire, amethyst, and diamond. Courtesy of Korite International; photo (c) Harold e Erica Van Pelt.

durable (including the ability to take a polish) to be manufactured into jewelry. In fact, freeform pieces of solid Ammolite over 100 ct have been reported (Wight, 1995). Iridescence produces the vivid colors in this material. The fact that Ammolite can be manufactured into jewelry distinguishes it from other iridescent materials obtained from various fossils (including other ammonites) that are frequently filmlike, have dull colors, or are otherwise unsuited for gem purposes. Nevertheless, because Ammolite usually occurs as thin, soft plates, it is found in jewelry primarily as assembled stones, such as triplets-a thin layer of Ammolite attached to a shale backing and covered with a synthetic spinel or quartz cap. Since 1980, both solid Ammolite and assembled Ammolite gemstones have become increasingly available. It is estimated that a total of about 600,000 pieces of Ammolite jewelry have been produced since significant commercial production began 20 years ago (P. Paré, pers. comm., 2001).

The purpose of this article is to update gemologists and jewelers on this unique gem material. For this study, we focused almost exclusively on material from the mining and manufacturing operations of Korite International Ltd. (henceforth Korite), Calgary, Alberta, because: (1) about 90\% of the commercially available material historically has, and still does, come from Korite's mines; (2) almost all published information on Ammolite is based on specimens obtained from this company; (3) several other smaller Ammolite miners and manufacturers were offered the opportunity to participate in this study, but only one (S. Carbone) agreed to do so; and (4) Korite allowed us unrestricted visitation to their mining and manufacturing operations, and supplied us with production data as well as specimens for research. In addition

Figure 2. Ammonites are extinct mollusks of the class Cephalopoda, order Ammonoidea. This brightly colored ammonite (47.3 $\mathrm{cm}$ in diameter) of the species Placenticeras intercalare, obtained from the Bearpaw Formation, near Lethbridge, Alberta, lived about 70 million years ago. The outer iridescent layer is the material from which gem Ammolite may be obtained, although more commonly it comes from naturally compacted and crushed specimens; complete specimens, such as the one pictured here, are typically more valuable left intact. Photo courtesy of Canada Fossils Ltd.

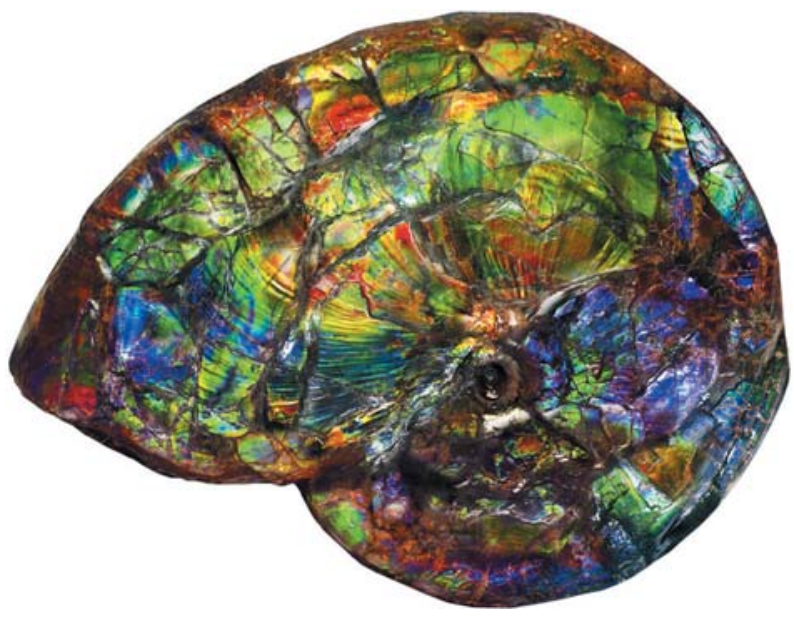




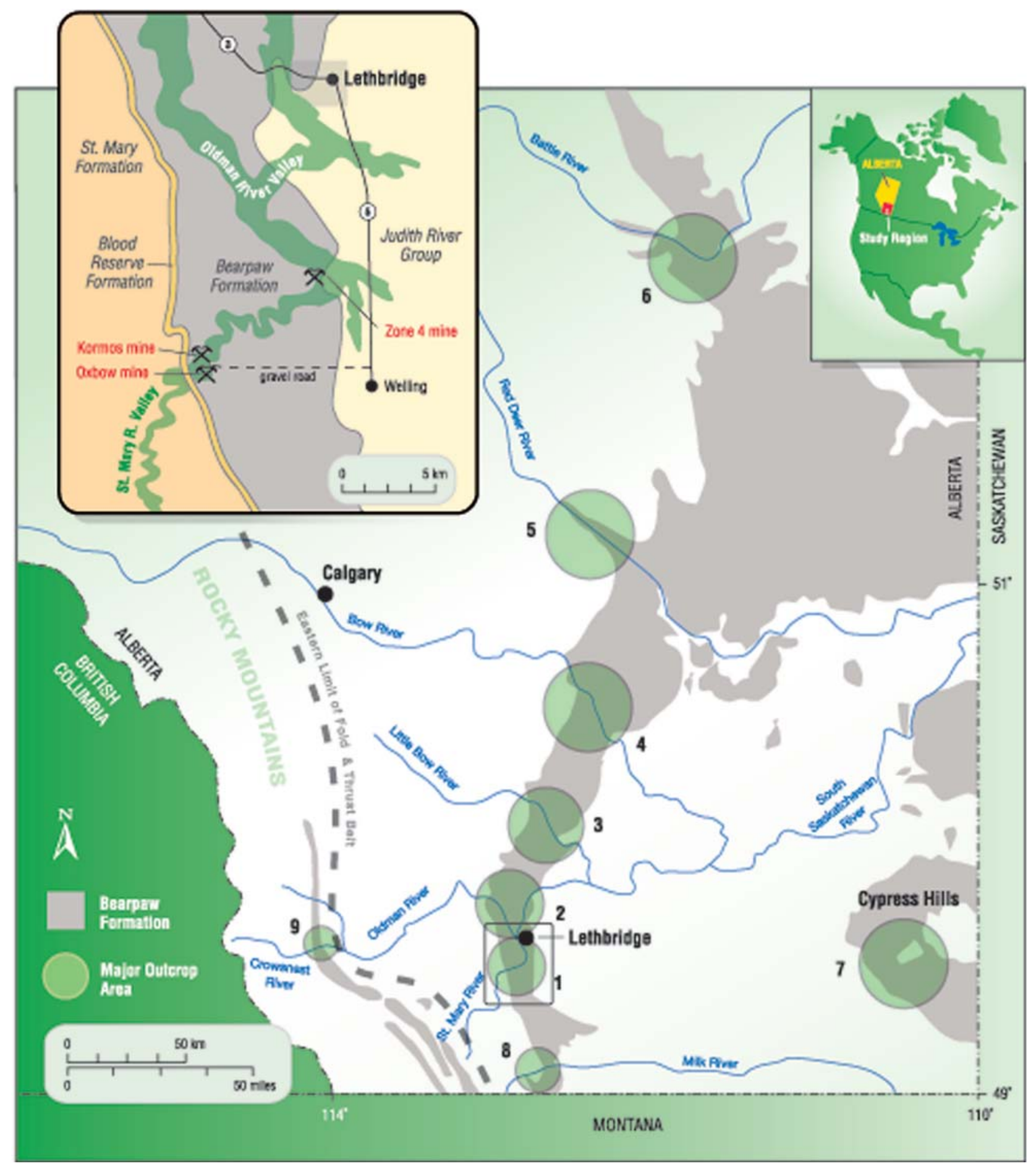

Figure 3. This map of the Bearpaw Formation of southern Alberta, Canada, shows both the bedrock geology and the location of the main Ammolite mining and collecting areas discussed in the text. Open circles represent areas of significant Bearpaw Formation outcrop, which is usually exposed in river valleys, where: 1 = St. Mary River, 2 = Oldman River, $3=$ Little Bow River, $4=$ Bow River, $5=$ Red Deer River, 6 = Battle River, 7 = Cypress Hills, $8=$ Milk River, and $9=$ Crowsnest River.

Ammonites can be collected at all locations, but Ammolite has only been reported from areas 1 through 5, with 1 being the best. Outcrops at 9 are located in the foothills of the Rocky Mountain fold and thrust belt. (Map modified from Tsujita and Westermann, 1998.) Inset: This "close-up" map shows the location of the three main mine sites discussed in this article: Kormos, Oxbow, and Zone 4. All are along the St. Mary River (location 1; map modified from Ward et al., 1982). 
to the gemological research described below, we studied outcrops and collected specimens from the St. Mary, Bow, Red Deer, and South Saskatchewan rivers, as well as the Cypress Hills area.

\section{HISTORY OF AMMOLITE AS A GEM MATERIAL}

Dowling (1917) provided the first description of the southern Alberta ammonites that yield Ammolite from samples recognized in 1908. However, the first recorded use of ammonite shell as a gem material was not until 1962, by amateur lapidaries who displayed their creations at a local gem show in Nanton, Alberta (Stafford, 1973a,b). Marcel Charbonneau, owner of a Calgary jewelry store, introduced the name Ammolite (the first trade name for this material) in 1967. He and Mike Berisoff, a geologist from Calgary (with whom he formed Ammolite Minerals Ltd.), were the first to collect Ammolite and create doublets for commercial purposes (Hadley, 1981a,b; Barnson, 2000). Ammolite Minerals Ltd. (1967-1970) collected rough Ammolite from the Kormos family ranch along the St. Mary River, near Lethbridge; this valley remains the source for most commercial Ammolite (see Mining Operations below). However, these early assembled Ammolites developed flaws (layers would separate), so they contacted Santo Carbone, a geologic technician with the Geological Survey of Canada, to improve the cutting and manufacturing techniques. Subsequently, Mr. Carbone was the first to discover fractured (type 1) Ammolite (see below; Hadley, 1981a,b; Kraus, 1982; Brown, 1984) on the Kormos ranch, in an area that would later be labeled the $\mathrm{K}$ Zone. The first published description of Ammolite in a major trade magazine appeared in 1969 (Leiper, 1969).

In the 1970s, Mr. Carbone formed a new commercial venture with Dr. Wayne Bamber and Thomas McArthur, both of Calgary. They introduced a second trade name, Calcentine, in 1975 (Crowningshield, 1977; Zeitner, 1978; Barnson, 2000). Coined in honor of the city of Calgary centennial (in 1975), the name was seldom used after 1981. In 1977, Mr. Carbone joined with Roy, Albert, and Sylvia Kormos to form Canadian Korite Gems (now Korite International). In 1979, Rene Vandervelde of Calgary (currently the chairman of Korite) purchased the Kormos family interests in Korite and brought modern business practices to the fledgling industry (Barnson, 2000). Mr. Carbone left Korite in
1980 and is currently manufacturing assembled Ammolite (see Manufacturing below). In 1981, Korite introduced a third trade name, Korite (Wight, 1981; Kraus, 1982; Brown, 1984). By the end of 1983, however, Ammolite had reappeared (Boyd and Wight, 1983; Pough, 1986). It was trademarked by Korite, who placed it in the public domain in 1997, so that Ammolite is now the standard designation for this material (Sinkankas, 1997).

Ammolite has also been referred to as "ammonite shell" (Stafford, 1973a,b,c) and simply as "gem aragonite" or "gem ammonite" (Barnson, 2000). Aapaok (Gem Reference Guide, 1995) was a trade name given to this material by certain members of the Blood Indian band during their brief (1980-1981) manufacture of Ammolite triplets from material obtained on their land (P. Paré, pers. comm., 2000). The first commercial appearance of Ammolite in the United States was in 1968, at gem shows in Seattle and Anaheim (Barnson, 2000). Ammolite was introduced in Germany, at Idar-Oberstein, in 1979 (Gübelin, 1980).

In the 1980s, Ammolite expanded its presence in the world market, the result not only of increased jewelry-grade supplies and improved methods of processing raw material into gemstones, but also of articles by a number of respected gemologists (Gübelin, 1980; Wight, 1981; Pough, 1986). In 1981, the CIBJO Colored Stones Commission recognized Ammolite as a gemstone, more specifically, as a "Permitted Name" in the "Variety and Commercial" columns against aragonite in their glossary (letter dated March 31, 1982 from E. A. Thomson to R. Vandervelde; Boyd and Wight, 1983; Dick, 1991). As a consequence of heavy Japanese tourism to the Canadian Rockies (in particular, Banff, Alberta) during the 1980s, which accounted for about $50 \%$ of sales of Ammolite and Ammolite triplets in 1985, this gem material became widely known in Japan ("Organic Alberta gemstone posed ...", 1985; Pough, 1986). Since 1983, when mining started at the open-pit Kormos mine, high-quality material has been offered regularly at the Tucson gem shows.

By 1998, the Canadian mining industry had also recognized the economic potential of Ammolite. At that time, the government of Alberta approved 119 leasing agreements for Ammolite mining, which covered 13,350 hectares in the names of 42 individuals and companies. Nevertheless, Korite is currently the only major producer. Today, work at the Kormos mine is temporarily suspended, and production comes from Korite's nearby $(0.5 \mathrm{~km})$ Oxbow 
whose shells are now the source of Ammolite.

Outcrops of the Bearpaw Formation are recognized in the Canadian provinces of Alberta and Saskatchewan, and in the U.S. state of Montana, where the type locality was first described and named after the Bearpaw Mountains (Hatcher and Stanton, 1903); the formation is known by a variety of other names in other states and provinces. However, there are no commercial occurrences of Ammolite outside of Alberta, although several attempts have been made to find such deposits (P. Paré, P. Evanson, and A. Ingelson, pers. comms., 2000).

At the Korite mine sites along the St. Mary River, the Bearpaw Formation is $232 \mathrm{~m}(761 \mathrm{ft})$ thick. It contains numerous bentonite /volcanic ash) layers and, in its upper two-thirds, three sandstone members: the Magrath, Kipp, and Rye Grass (figure 5). Since Ammolite is found in distinct horizons within the Bearpaw Formation, knowledge of

Figure 5. This stratigraphic section of the Bearpaw Formation shows the location of important sandstone members, the double-ash (bentonite) layer, and the two known economic Ammolite-bearing horizons (K Zone and Zone 4; see text) in the St. Mary River area of southern Alberta; the lateral extent of these units is limited. Modified from Link and Childerhose (1931).

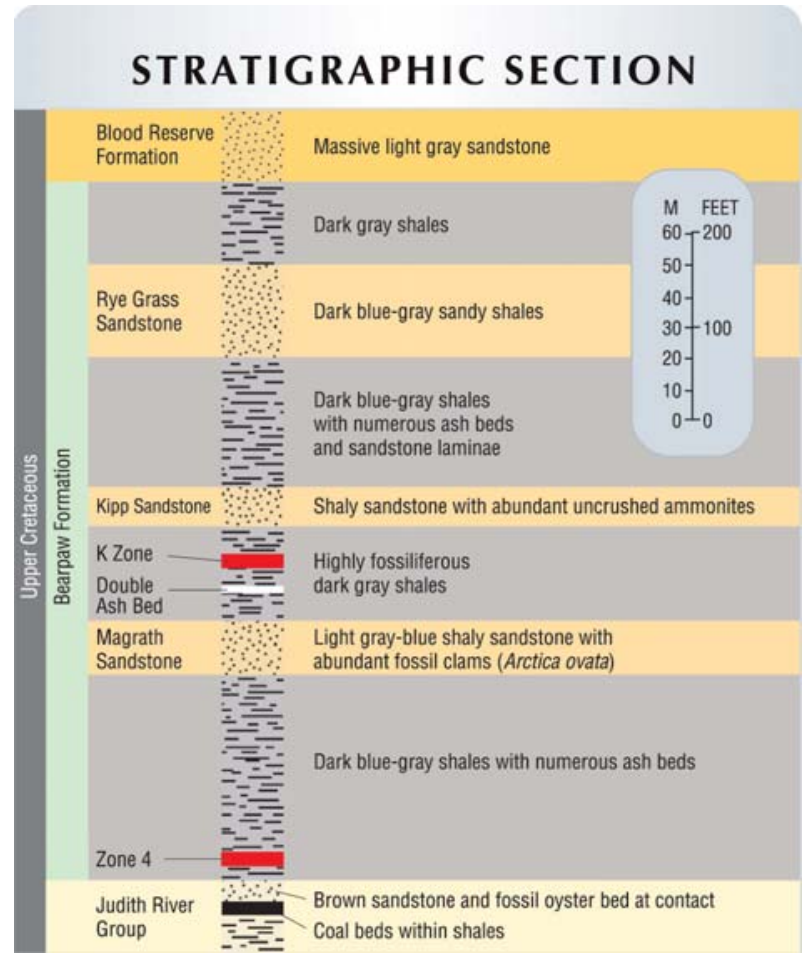

this stratigraphy helps geologists pinpoint gem deposits.

The Bearpaw Formation contains numerous layers with hard siderite $\left(\mathrm{FeCO}_{3}\right)$ concretions. These concretions form by precipitation from an aqueous solution around a nucleus (Jackson, 1997) that is commonly a fossil, such as an ammonite. It is within such ironstone concretions that gem-quality Ammolite is typically (but not exclusively) found. The concretion's overall shape will commonly mimic the shape of its nucleus, thus giving an indication of its economic potential. For example, ammonite-bearing concretions are typically disk shaped (generally 20-60 cm, but as large as $1 \mathrm{~m}$; see, e.g., figure 6), whereas round or spherical concretions rarely contain ammonites. Small- to mediumsize concretions, $15-60 \mathrm{~cm}$ in diameter, found in the K Zone (see below) yield the best Ammolite for Korite (P. Paré, pers. comm., 2000).

Extensive glaciation in southern Alberta during the last southerly advance $(22,000-36,000$ years ago) of ice as part of the Pleistocene "ice age" resulted in the deposition of glacial overburden. At the Korite mine sites, these glacial deposits are about 15-30 m thick. Fortunately, the St. Mary River has cut into both the glacial deposits and the Bearpaw Formation, exposing ammolite-bearing horizons in certain places. However, even here the Bearpaw Formation is buried under a veneer of alluvial gravels and sediments, generally $2-5 \mathrm{~m}$ thick. Since the formation dips $3^{\circ}$ to $6^{\circ}$ to the west at all Korite 


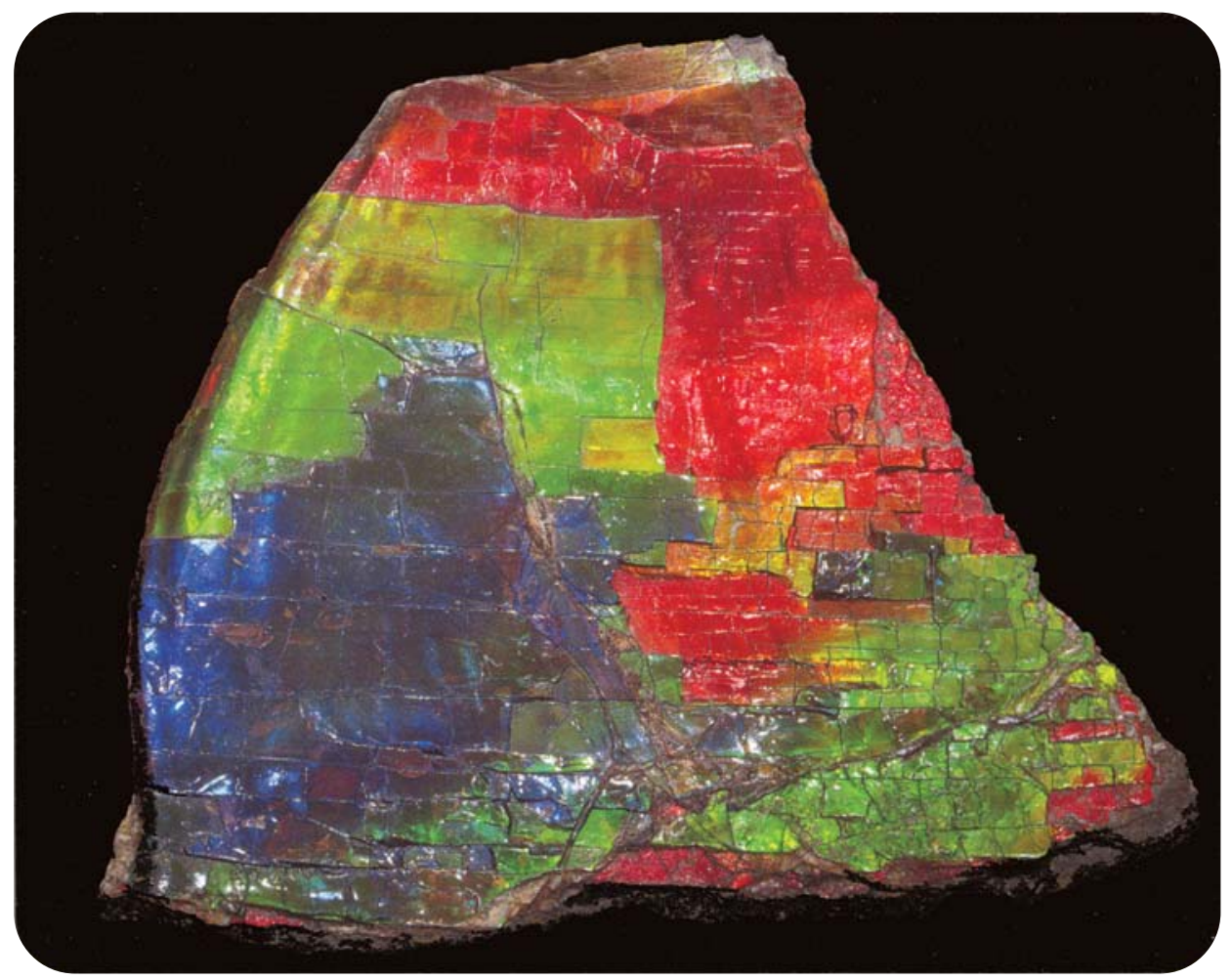

Figure 7. This exceptional specimen of Zone 4 Ammolite shows (almost) the complete color spectrum. Such material, which is of nonconcretionary origin, occurs as sheets (referred to as type 2; see text) and has not been fractured by geologic processes. Note the large color panes (flat areas of uniform color), typical of type 2

Ammolite, as compared to the smaller color panes of type 1 material (again, see figure 1). The specimen is $11 \mathrm{~cm}$ along the longest (bottom) edge. Courtesy of Korite International; photo (C) Harold et Erica Van Pelt.

mine sites (P. Paré, pers. comm., 2000), the K Zone is too deeply buried under much of the neighboring territory to exploit at this time. A short distance to the east, it has been eroded away. Due to the effects of groundwater and various other natural processes (e.g., extreme temperatures, frost), the aragonite in most ammonite shells in the oxidized zone-the upper $3 \mathrm{~m}$ of the Bearpaw Formation, where it contacts glacial or alluvial deposits-has been converted to white calcite ("calcified ammonite"), which has no gem value.

\section{DISTRIBUTION AND CHARACTERISTICS OF AMMONITES AND AMMOLITE IN THE BEARPAW FORMATION}

General. Although fossil ammonites are found throughout the Bearpaw Formation in southern Alberta, Ammolite distribution varies widely with respect to both quantity and quality. Almost all the ammonites that produce marketable Ammolite have been mined or collected in the western part of southern Alberta. Ammolite from other parts of the Bearpaw Formation may be too thin or flaky to withstand polishing, although some can be stabilized with an epoxy resin or similar material for manufacture into gemstones (see below). Moreover, some Ammolite-bearing horizons within the Bearpaw
Formation are too deeply buried to allow for commercial extraction (Korite's current open-pit mining methods are only economic to depths of $20 \mathrm{~m}$; P. Paré, pers. comm., 2000). There have been many commercial failures as a result of these factors.

There is no known exploration technique (e.g., geophysical, remote-sensing) to locate or evaluate buried ammonites (although ground-penetrating radar may have potential in this regard). Only expensive test mining has proved helpful. Korite alone has excavated 20 trenches $16 \mathrm{~m}$ deep $\times 15 \mathrm{~m}$ wide $\times 5-30 \mathrm{~m}$ long) and 30 test pits $(9 \mathrm{~m}$ deep $\times 5$ $\mathrm{m}$ diameter) throughout southern Alberta since 1977 (P. Paré, pers. comm., 2000).

In the course of exploration and mining, Korite has identified two horizons or "zones" within the Bearpaw Formation-the K Zone and Zone 4-that contain commercial quantities of Ammolite. The company also has recognized two distinct types of Ammolite that are associated with these two zones. Type 1 is fractured Ammolite (same as Barnson's [2000] "compacted Ammolite"), that is, Ammolite that has undergone compaction and fracturing, with the fractures subsequently "healed" naturally with carbonate and/or clay matrix material. This type does not require stabilization for manufacture into jewelry (again, see figure 1). Ammolite from the K Zone is typically found in concretions that yield 
TABLE 1. Characteristics of $\mathrm{K}$ Zone and Zone 4 ammonites and Ammolite.

\begin{tabular}{|c|c|c|c|}
\hline Attribute & K Zone & $\begin{array}{c}\text { Zone } 4 \\
\text { Concretionary }\end{array}$ & $\begin{array}{c}\text { Zone } 4 \\
\text { Non-concretionary }\end{array}$ \\
\hline $\begin{array}{l}\text { 1. Fossil specimen } \\
\text { potential and } \\
\text { quality of } \\
\text { Ammolite }\end{array}$ & $\begin{array}{l}\text { Poor-quality fossil speci- } \\
\text { mens (due to compaction } \\
\text { and presence within con- } \\
\text { cretions); high-quality } \\
\text { Ammolite }\end{array}$ & $\begin{array}{l}\text { Poor-quality fossil speci- } \\
\text { mens and lower-quality } \\
\text { Ammolite than K Zone } \\
\text { (constitutes } 50 \% \text { of Zone } \\
4 \text { material) }\end{array}$ & $\begin{array}{l}\text { Few complete fossils; } \\
\text { most ammonites are com- } \\
\text { pacted but not fractured; } \\
\text { high-quality Ammolite }\end{array}$ \\
\hline $\begin{array}{l}\text { 2. Type and thick- } \\
\text { ness of Ammolite } \\
\text { layer }\end{array}$ & $\begin{array}{l}\text { Type } 1 \text { (fractured); film- } \\
\text { like to } 8 \mathrm{~mm} \text { thick in } \\
\text { rough }\end{array}$ & Same as $\mathrm{K}$ Zone & $\begin{array}{l}\text { Type } 2 \text { (sheet); thickness } \\
\text { same as K Zone }\end{array}$ \\
\hline $\begin{array}{l}\text { 3. Durability of } \\
\text { Ammolite }\end{array}$ & $\begin{array}{l}\text { Stable, does not deterio- } \\
\text { rate, resists wear with } \\
\text { normal jewelry usage }\end{array}$ & Same as $\mathrm{K}$ Zone & $\begin{array}{l}\text { Sheet-like material may } \\
\text { delaminate }\end{array}$ \\
\hline $\begin{array}{l}\text { 4. Stabilization of } \\
\text { Ammolite }\end{array}$ & Rarely required & Rarely required & $\begin{array}{l}\text { Commonly, but not } \\
\text { always, required }\end{array}$ \\
\hline $\begin{array}{l}\text { 5. Size of Ammolite } \\
\text { panes (i.e., flat } \\
\text { areas of uniform } \\
\text { color); and thick- } \\
\text { ness of healed } \\
\text { fractures between } \\
\text { panes }\end{array}$ & $\begin{array}{l}\text { Small panes (average 2-5 } \\
\text { mm, maximum } 1 \mathrm{~cm} \text { ); } \\
\text { fracture fillings between } \\
\text { panes average } 1 \mathrm{~mm} \text {; in } \\
\text { general, smaller panes } \\
\text { with thin healed fractures } \\
\text { result in the most durable } \\
\text { Ammolite }\end{array}$ & $\begin{array}{l}\text { Larger panes than in } \mathrm{K} \\
\text { Zone (average } 5-7 \mathrm{~mm} \text {, } \\
\text { maximum } 1 \mathrm{~cm} \text { ); healed } \\
\text { fractures between panes } \\
\text { are thicker }(2-3 \mathrm{~mm}) \text { than } \\
\text { in K Zone Ammolite, which } \\
\text { detracts from beauty }\end{array}$ & $\begin{array}{l}\text { Relatively large panes } \\
\text { (typically } 2-3 \mathrm{~cm} \text {, maxi- } \\
\text { mum } 10 \mathrm{~cm} \text { ); no fractures }\end{array}$ \\
\hline $\begin{array}{l}\text { 6. Color display of } \\
\text { Ammolite }\end{array}$ & $\begin{array}{l}\text { Red, orange, yellow, } \\
\text { green, and blue are char- } \\
\text { acteristic. "Full color spec- } \\
\text { trum" is common except } \\
\text { for violet, which is rare }\end{array}$ & $\begin{array}{l}\text { Orange, yellow, and green } \\
\text { are most common, with } \\
\text { no red and little blue }\end{array}$ & $\begin{array}{l}\text { Same colors as } \mathrm{K} \text { Zone } \\
\text { (except blue is more } \\
\text { common), but usually } \\
\text { only two predominate }\end{array}$ \\
\hline
\end{tabular}

type 1 material. Type 2 is sheet Ammolite (same as Barnson's [2000] "noncompacted Ammolite"), that is, Ammolite that has undergone compaction but not the fracturing and subsequent healing stages (figure 7). For manufacture into jewelry, some type 2 Ammolite must first be stabilized, as it may have a tendency to delaminate. Ammolite from Zone 4 that does not originate from concretions is commonly type 2 material. Table 1 lists the characteristics of each type of Ammolite and the zone in which it is typically found.

K Zone. The vast majority of commercially available Ammolite has been derived from concretions in the $\mathrm{K}$ (for Korite) Zone. About $3.6 \mathrm{~m}$ thick, it is located approximately $120 \mathrm{~m}(400 \mathrm{ft})$ below the top of the Bearpaw Formation, between the Kipp and Magrath sandstone members (again, see figure 5) and 9-12 $\mathrm{m} \mathrm{(30-40} \mathrm{ft)} \mathrm{above} \mathrm{the} \mathrm{double-ash}$ (bentonite) layer identified by Link and Childerhose (1931), as seen in figure 8. Complete, museum-quality ammonites (such as the one pictured in figure 2) from the K Zone are very rare; most have been crushed (P. Paré, pers. comm., 2000). Both the Oxbow and Kormos open-pit
Figure 8. This view shows a cliff face in the Bearpaw Formation (the gray stratum right above the green valley floor) on the St. Mary River, $0.5 \mathrm{~km}$ northeast of the Kormos mine. The thin, white double-ash layer (see arrows) helps geologists locate the most important Ammolite-bearing horizon (the K Zone), which is typically 9-12 $\mathrm{m}$ (30-40 ft) above this marker. Also visible on the surface (tan color at the right forefront) are the glacial sediments that blanket this area. Photo taken looking north; courtesy of Korite International.

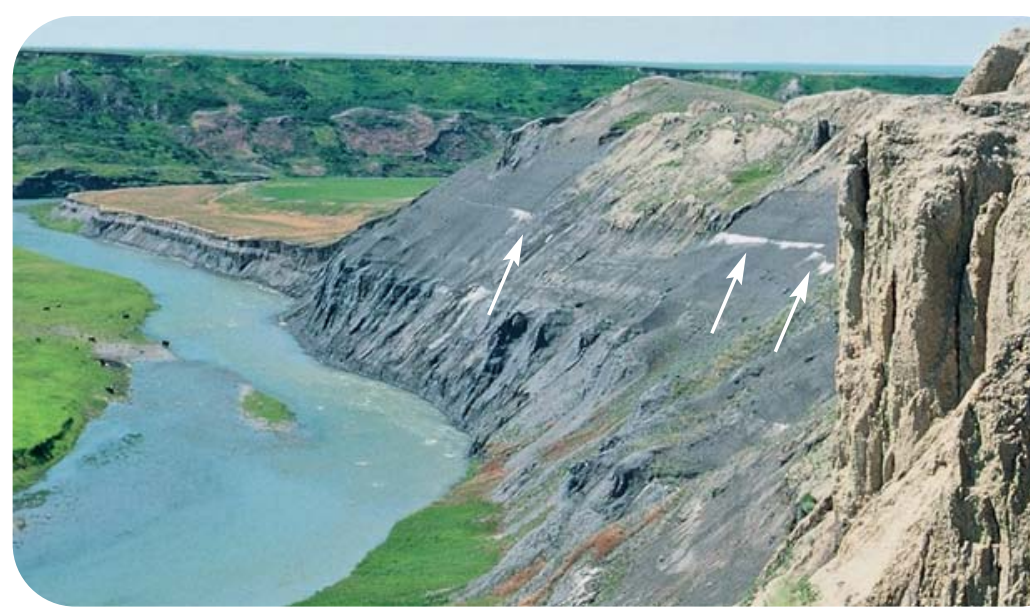


mines are positioned to take advantage of the outcropping of the K Zone.

Zone 4. This approximately 2-m-thick horizon (also

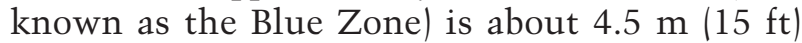
above the base of the Bearpaw Formation (again, see figure 5). About half of the ammonites derived from this unit were never encased within concretions ("non-concretionary"), and these typically yield type 2 sheet Ammolite. The concretionary ammonites from Zone 4, similar to those in the K Zone, have been compacted, fractured, and healed (type 1 Ammolite) and do not need to be stabilized. However, this Zone 4 fractured material has certain features (e.g., it displays none of the red and little of the blue colors) that are less desirable than K Zone fractured Ammolite; consequently, Korite does not currently manufacture it into gemstones. The two varieties of Ammolite are also found in distinct layers within Zone 4.

\section{THE ORIGIN OF AMMOLITE}

While Jurassic and Cretaceous rocks all over the world contain abundant fossil ammonites, so far Ammolite has been obtained from only a few localities in southern Alberta and only within the Bearpaw Formation. To date, just two species of ammonite, Placenticeras meeki and $P$. intercalare, have yielded marketable Ammolite; other fossil ammonoids found in the same formation, such as Baculites compressus, have not yielded iridescent material of sufficient thickness and durability for use in jewelry (P. Paré, S. Carbone, and P. Evanson, pers. comms., 2000). These facts suggest that some unusual circumstances are responsible for the formation of Ammolite.

The Depth-of-Burial Factor. As part of our fieldwork, we collected Ammolite from various parts of Alberta and met with several individuals involved in Ammolite exploration. Our findings indicate that the quality of Ammolite improves westward in southern Alberta. For example, the colors exhibited by fossil ammonites from the Cypress Hills area (white with faint iridescence) and the Bow River area (typically red-brown)-in southeast and south-central Alberta, respectively (again, see figure 3)-are significantly less vivid than those found in ammonites along the St. Mary River valley in the southwest. As shown in Mossop and Shetsen (1994), rocks in the western part of southern Alberta (e.g., the St. Mary River area) underwent significantly more burial than those in the eastern part (e.g., the Cypress Hills area). On the basis of thermal maturation studies of organic material of the Judith River Group, which immediately underlies the Bearpaw Formation (England and Bustin, 1986), we estimate that the Bearpaw Formation was buried to a depth of about $4 \mathrm{~km}$ in the St. Mary River area (and has since been uplifted and exposed at the surface). The Bearpaw Formation in southeast and south-central Alberta, on the other hand, was not buried as deep.

We propose that the increased depth of burial resulted in a form of diagenesis (i.e., alterations undergone by sediment subsequent to deposition), as yet unidentified, on ammonite shells within the Bearpaw Formation of southwestern Alberta, specifically in the St. Mary River area. The diagenesis intensified the colors on some ammonite shells. During this process, however, the aragonite did not convert to calcite, the more stable form of $\mathrm{CaCO}_{3}$, as would be expected in 70-million-year-old material. If such conversion had occurred, Ammolite would not have formed. Niedermayr and Oehner (1995) and Niedermayr (1999) suggested that high amounts of $\mathrm{Fe}$ and/or $\mathrm{Mg}$ in the Bearpaw Formation (including the concretions) might be a factor in inhibiting the conversion.

Pough (1986) was the first to suggest that alteration by burial (accompanied by compression and alteration of the organic matter within the nacre) might be a factor in the formation of Ammolite, but he did not discuss the effects of the relative differences in the depth of burial of ammonite shells in the Bearpaw Formation between eastern (little or no iridescence) and western (vivid iridescence) Alberta. However, P. Paré (pers. comm., 2000) has noted that only rarely can shell from Placenticeras ammonites obtained from the Kipp sandstone member (sandy shale; again, see figure 5) of the Bearpaw Formation, in the St. Mary River valley, be used as a source of Ammolite. This suggests that the high sand content of the Kipp member may have prevented or impeded Ammolite formation. Clues to the origin of Ammolite may also be found in the original architecture or chemical constituents (e.g., the organic component, trace elements) of the shell, since only certain ammonite species are predisposed to forming Ammolite. Additional research is needed to explain fully the process that has occurred.

Fractured (Type 1) versus Sheet (Type 2) Ammolite. An explanation for the origin of the two types of 
Ammolite, fractured (type 1) and sheet (type 2), can be found in the rate and extent of sediment infill into ammonite shells following the death of the animal. After Placenticeras ammonites died, their shells sank to the bottom of the Bearpaw Sea. Some of these shells were quickly buried, with little or no sediment filling the empty shell chambers. Their internally unsupported shells were subsequently compacted and fractured (and later healed), which resulted in type 1 Ammolite (K Zone material; again, see figure 1). However, it is likely that the chambers in those shells that were not buried rapidly would have filled with sediment, so that the ammonite shell was internally supported. Such shells would resist fracturing during compaction, thus giving rise to type 2 Ammolite (sheet material characteristic of Zone 4; again, see figure 7). Ward et al. (1982) were the first to note that the lack of sediment infill into the empty chambers of Placenticeras shells following burial resulted in a high ratio of compacted shells in several zones; however, they did not extend this observation to the origin of fractured type 1 Ammolite within the Bearpaw Formation. Type 1 Ammolite is usually (but not always) found within ironstone concretions, whereas type 2 Ammolite is not (again, see table 1), which suggests that concretions play a role in developing the type 1 material.

\section{MINING OPERATIONS}

Surface Collecting. Since the early 1960s, Ammolite has been collected by amateurs and small commercial lapidaries from the vicinity of the St. Mary River (e.g., Stafford, 1973a). These finds occur in the riverbed and along the valley walls, where ammonites are exposed by erosion. Subsequently, Ammolite was discovered in the gravel bars of numerous other rivers throughout southern Alberta where the Bearpaw Formation is exposed (again, see figure 3); mining claims currently are held on the Bow, Little Bow, Oldman, and Red Deer rivers. We estimate that $5 \%-7 \%$ of current Ammolite production is derived from surface-collected material, all by small producers. An additional $2 \%$ of the total is obtained by small producers from small test pits in the Bearpaw Formation. Similarly, about 1\% of Korite's production is from concretions collected on the surface in the St. Mary River valley (P. Paré, pers. comm., 2000).

Open-pit Mines. Only two mines-Kormos and Oxbow-have produced gem-quality Ammolite in significant quantities. Both are open-pit operations on the banks of the St. Mary River (again, see figures 3 and 4). Essentially all (99\%) of Korite's production has come from open-pit mines, with the remainder from the surface source mentioned above (P. Paré, pers. comm., 2000). The Kormos mine was active from 1983 to 1994; since then, operations have been suspended, although long-range plans are to reactivate the mine. Production at the Oxbow mine started in 1994 and has continued to the present.

In recent years, Korite has mined between 2 and 5 acres annually to achieve a production of about 57,000 finished pieces of Ammolite and assembled Ammolite gems per year (P. Paré, pers. comm., 2001). Between 1983 and 1999, Korite excavated 40 acres of land, of which 35 acres have been restored to their natural state.

Mining Methods. Initially, the topsoil, sand, and gravel layers are stripped and stockpiled for later site reclamation. The underlying Bearpaw Formation is then excavated with a large backhoe (again, see figure 4). Blasting is not required because the shales are so easily worked. Mining is conducted from March through November, as winter operations of this type are difficult in Canada.

Most Ammolite is protected in concretions that are more durable than the surrounding shale. This has led to the development of a rather simple, but effective and economical, mining process. Korite's mining team consists of four individuals: a backhoe operator, a dump truck operator, and two sorters or "spotters." The backhoe operator excavates the shale and then "sifts out" the soft, uneconomic material with a side-to-side motion of the machine, leaving the hard concretions in the shovel. The spotter carefully observes material in the bucket of the backhoe, looking for disk-shaped concretions (figure 9), which represent only about $10 \%$ of the concretions found in the K Zone (P. Paré, pers. comm., 2000). Waste shale is removed by dump truck and also stockpiled for reclamation.

After the spotter has closely inspected the diskshaped concretions, he uses a sledgehammer to break open those he feels have the potential for Ammolite (figure 10). The Ammolite attached to ironstone matrix is placed in "tubs," each of which holds about 45 liters of material. The Oxbow mine produces about five tubs of raw material daily $(\mathrm{P}$. Paré, pers. comm., 2000). After the concretions are trimmed with hammers and a rock saw at the mine, daily production is reduced to about one tub of 


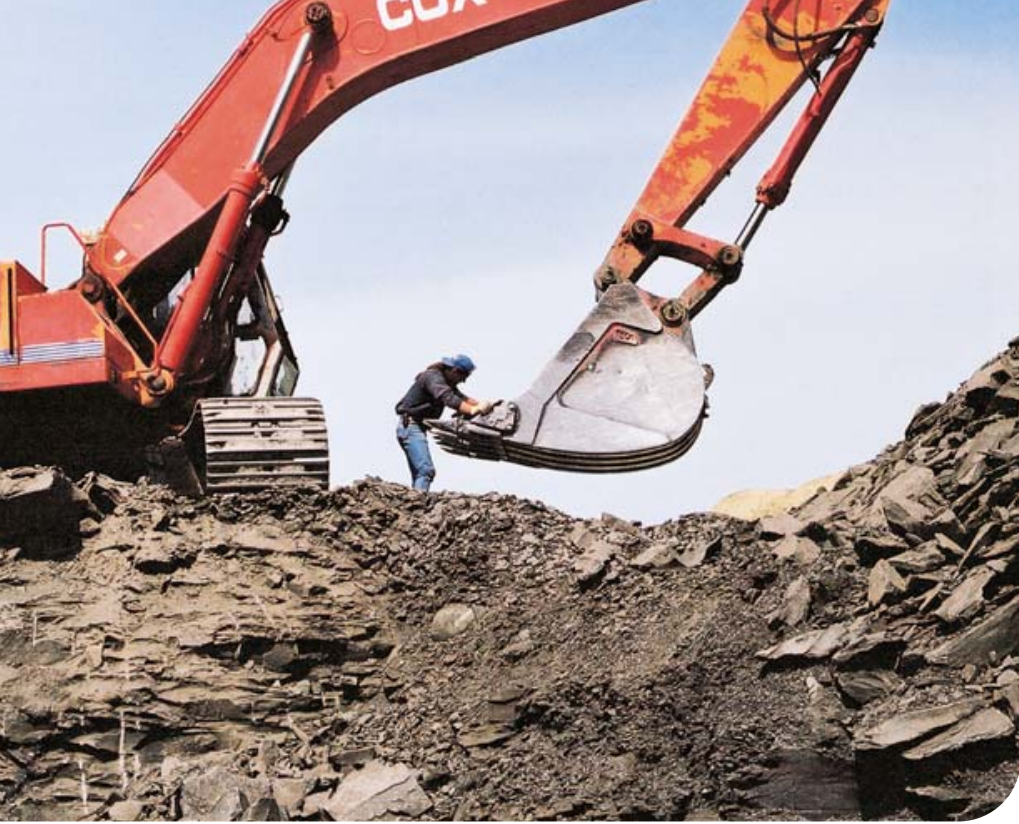

Figure 9. As the backhoe removes the Bearpaw shale at the Oxbow mine, a "spotter" searches the bucket for disk-shaped concretions. Note how friable the shale is. Photo courtesy of Korite International.

Figure 10. This close-up shows a "spotter" after he has broken open a promising concretion (note the colors on the broken layer). Only disk-shaped concretions, which represent about $10 \%$ of the concretions in the K Zone, will contain Ammolite. Photo by Art Barnson, Barnson Photography.

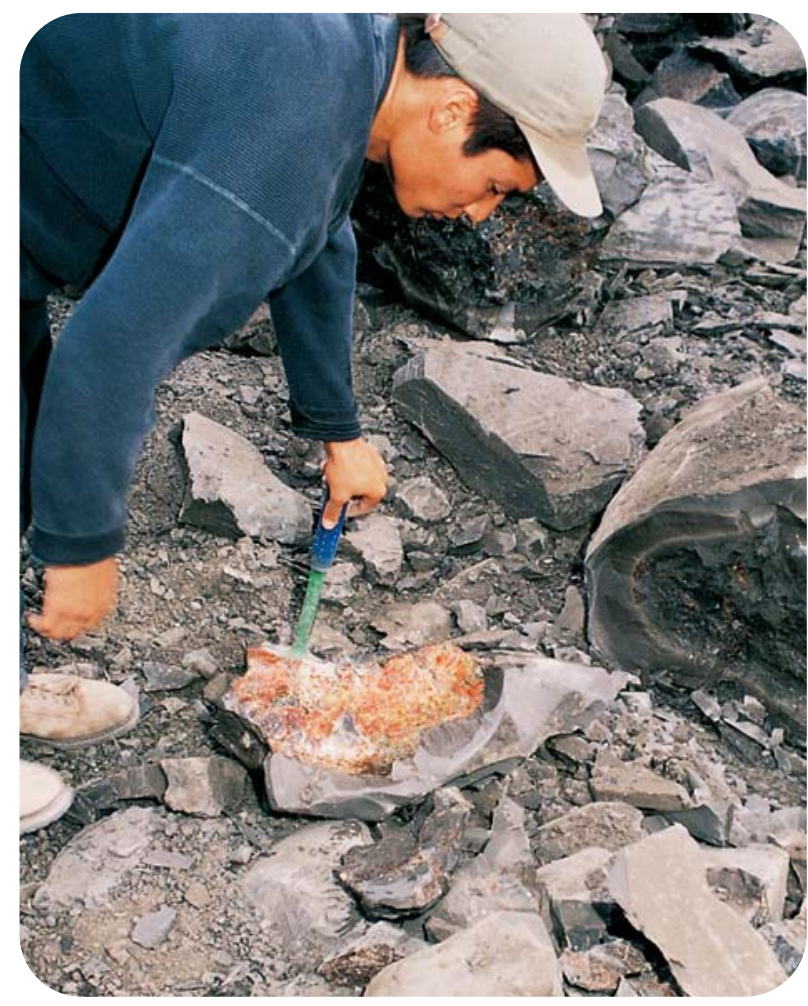

Ammolite on matrix, which eventually is shipped to the main manufacturing facility in Calgary. The authors did observe much colorful material being rejected at the mine site and thrown back into the pit. It was explained that this material was too thin, patchy, or irregular to use in jewelry.

The mining method described above is only effective for Ammolite encased in concretions and undoubtedly would destroy less durable material. For example, Zone 4 non-concretionary (type 2 sheet) material is mined by Korite in a slightly different manner. After the overburden has been removed, excavators dig into the zone until any sign of Ammolite colors appear. Material is then collected by hand, which makes this a much slower operation. The economic potential of Zone 4 was first recognized in 1996, and mining at the Zone 4 pit began in August 1999.

Exploitation of the K Zone and Zone 4 in other areas of southern Alberta is constrained by the amount of overburden that must be removed for open-pit mining (again, see figure 8). Underground mining is not feasible in the soft, friable shales of the Bearpaw Formation.

\section{AMMOLITE PRODUCTION}

Korite has the only ongoing mechanized mining operation; all other Ammolite mining activities are artisanal, that is, small workings for which accurate records are seldom available. Thus, we are aware of no reliable production statistics for Ammolite other than those from Korite. Production of finished Ammolite by Korite consists predominantly of triplets, but there are also "solids" and doublets (P. Paré, pers. comm., 2001). Triplets (sold by size) consist of a colorless cap and a dark backing that are attached to a thin Ammolite layer (again, see figure 1 ), whereas doublets (sold by carat weight) are an Ammolite layer attached to a backing (without a cap). Two types of solids are produced: two-sided (Ammolite on both sides; figure 11), and one-sided (a natural assemblage of Ammolite attached to its shale backing); each is sold by the carat (see Visual Appearance below for average weights and dimensions in each category). At Korite, stabilization with an epoxy resin is applied to some, but not all, solids and doublets, but never to the Ammolite used in triplets; material derived from the $\mathrm{K}$ Zone is rarely stabilized (P. Paré, pers. comm., 2001). Other manufacturers have recently introduced other types of assembled stones (see Manufacturing below), but 
their impact on overall Ammolite availability has not yet been felt.

Major production began in 1983, with the opening of the Kormos mine. That first year, 12,211 finished pieces were fashioned $(12,004$ Ammolite triplets, 183 one-sided solids, and 24 two-sided solids; none of this material was stabilized) from 20,500 tonnes of excavated shale (P. Paré, pers. comm., 2001). However, much of this early production included low-grade Ammolite that would not have been manufactured into gems in recent years (P. Paré, pers. comm., 2001). Some reports of early Korite production ("Ammolite. New gems from...", 1984; "Organic Alberta gemstone posed ...", 1985; Vandervelde, 1993) suggested that less than 6,000 tonnes of shale was excavated in 1983, but this is not correct (P. Paré, pers. comm., 2001). Korite's production in 1999 (the most recent year for which Korite made data available to the authors), consisted of 55,000 Ammolite triplets, 1,500 Ammolite doublets (about $50 \%$ stabilized), 500 one-sided solids (about 50\% stabilized), and only 25 two-sided solids (none stabilized); for a total of 57,025 finished stones (P. Paré, pers. comm., 2001). This production was derived primarily from the Oxbow mine, with the exception of small amounts from the Zone 4 mine and surface-collected material. At present, the
Zone 4 mine contributes about $10 \%$ by volume, but only $5 \%$ by value, to Korite's overall production (P. Paré, pers. comm., 2001). The authors believe that the Korite operations represent about $90 \%$ of the production throughout Alberta. As such, we estimate that the total annual production of Ammolite (all categories) is currently more than 63,000 finished stones.

Huge amounts of rock are mined to obtain a relatively small amount of gem-quality Ammolite. In 1999 , from 165,000 tonnes of excavated shale only 105,000 carats $(21 \mathrm{~kg})$ of Ammolite solids and assembled gemstones (including the backings but not the caps) were obtained (P. Paré, pers. comm., 2001). This is equivalent to a mere 0.64 ct per tonne of shale. Because the Ammolite layer in an average triplet is only $0.1 \mathrm{~mm}$ thick, the actual finished carat weight/tonne of Ammolite is, therefore, considerably less once the backing weight is subtracted.

\section{STABILIZATION OF AMMOLITE}

Stabilization-that is, impregnation of the material under pressure with an epoxy or other substanceis usually required to strengthen type 2 (sheet) Ammolite so that it can be manufactured into jewelry as solids or doublets. (As stated above, the

Figure 11. This rare two-sided solid Ammolite $(3.1 \times 4.2 \mathrm{~cm})$ shows predominantly red and green on one side (left) and blue and green on the other. This piece was polished from unstabilized sheet material from Zone 4 and is $2 \mathrm{~mm}$ thick. Courtesy of Santo Carbone; photo (C) Harold et Erica Van Pelt.
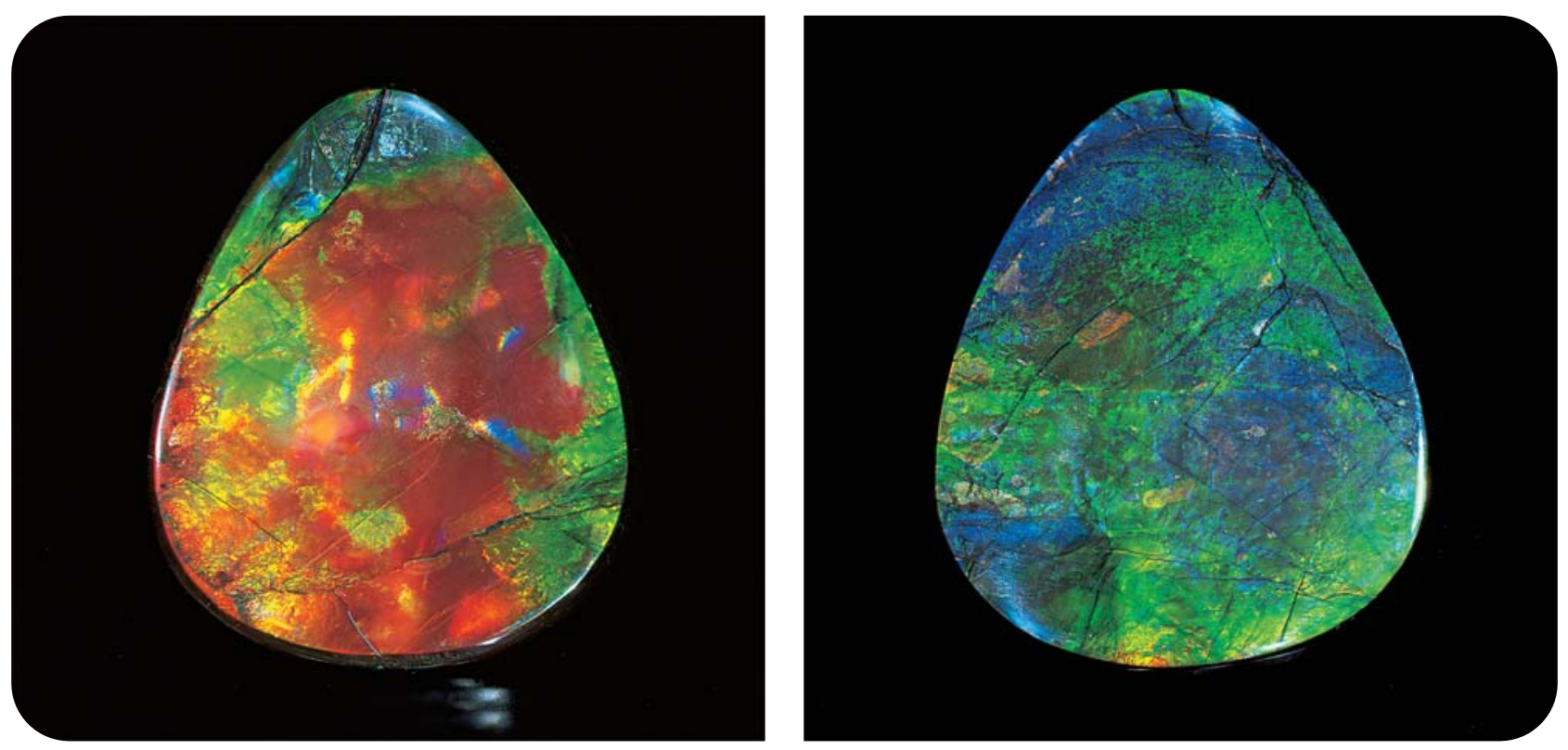


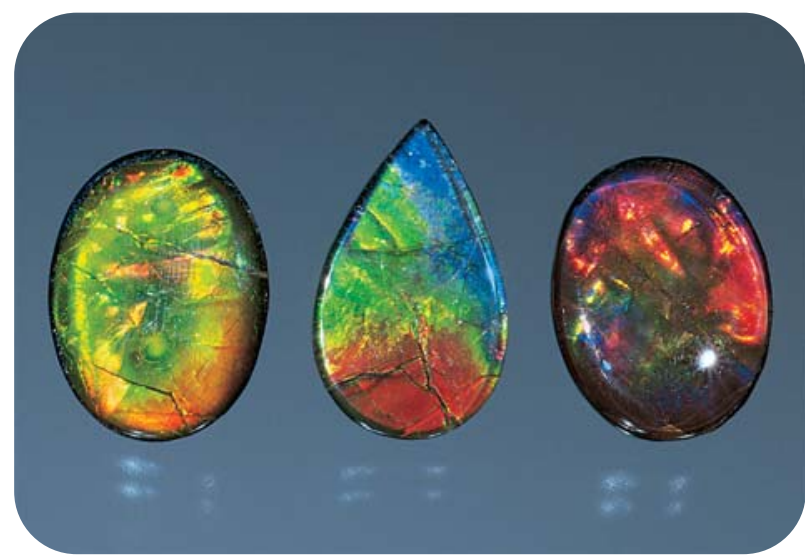

Figure 12. "Quadruplets"-here, the $1.9 \times 1.5 \mathrm{~cm}$ oval on the left and the $2.0 \times 1.5 \mathrm{~cm}$ oval on the right-are fashioned from two Ammolite layers with a shale backing and a synthetic spinel or quartz cap. The pear-shaped piece in the center is a triplet. Quadruplets courtesy of Santo Carbone; triplet courtesy of Korite International. Photo (C Harold et) Erica Van Pelt.

Ammolite incorporated into triplets is not stabilized.) Although it is likely that some Ammolite was stabilized and sold as early as the 1970s (see, e.g., Sinkankas, 1997), details of such treatments are

Figure 13. Auroralite is a patented assembled stone made by using fragments of Ammolite that are attached with epoxy to a carborundum backing and then capped with a transparent colorless material. The resulting mosaic exhibits a glitter effect. The larger of the two stones shown here measures $16 \times 12 \mathrm{~mm}$, and the smaller is $14 \times 10$ mm. Courtesy of Aurora Canadian Jewellery.

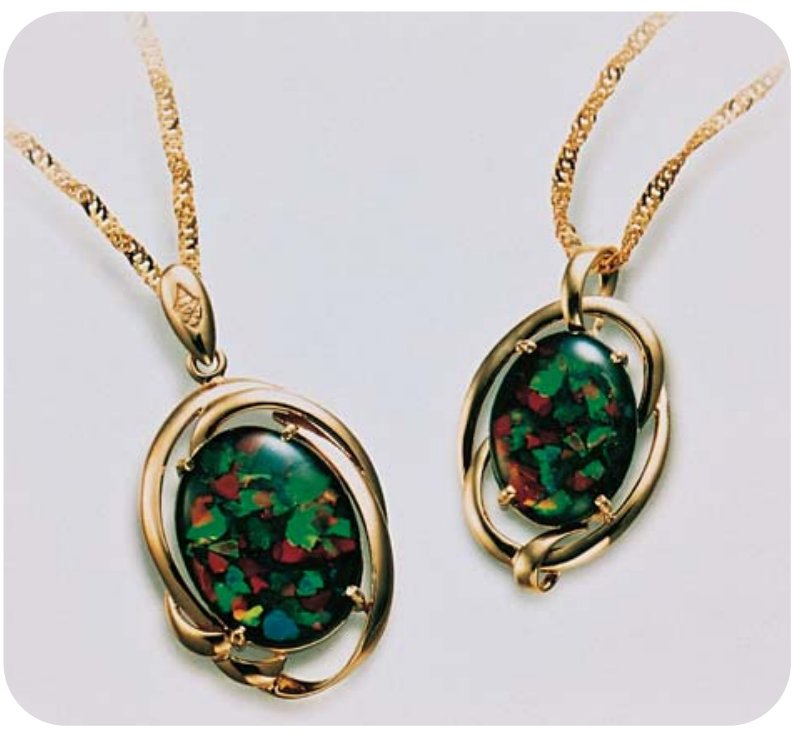

lacking. Koivula and Kammerling (1991) were the first to document the stabilization of Ammolite, specifically a plastic impregnation that was used as early as 1989.

Korite began stabilizing some type 2 (sheet) Ammolite from Zone 4 in 1998. Before fashioning, Korite impregnates the rough material under pressure (1500 psi) by forcing a commercially available polymer (an epoxy resin) into the Ammolite layers with nitrogen gas (P. Paré, pers. comm., 2000). Other manufacturers may use different procedures and materials.

During the stabilization process, the entire sample is immersed in polymer. Subsequent polishing removes the epoxy on the surface, and the only remaining epoxy is between the layers. We studied six such specimens by viewing them microscopically (incident illumination) on their polished edges. It was possible to recognize the impregnation, though with difficulty, at magnifications greater than $30 \times$. The impregnation appears as very thin seams of epoxy between the layers, and as small epoxy-filled voids.

Approximately $50 \%$ of the Ammolite solids and doublets that Korite placed on the market in 1999 were stabilized. Korite sells stabilized Ammolite for between one-third to one-half the price of untreated material of equivalent grade (P. Paré, pers. comm., 2000). The authors believe that perhaps one-third of the non-Korite production is also stabilized in some way, since it is mainly derived from surface-collected sheet material.

Some color enhancement of Ammolite triplets has been reported by Barnson (2000), where triplet backings (see Manufacturing below) are painted blue, green, or pink to enhance otherwise poorly colored Ammolite. We could not confirm use of this technique (P. Paré and S. Carbone, pers. comms., 2001). Other enhancement techniques that are effective with some gemstones, such as heat treatment and irradiation, are not applied to Ammolite as they would damage the material.

\section{MANUFACTURING}

Early descriptions of Ammolite manufacturing procedures, which were based on surface-collected materials (Stafford, 1973b,c; Jarand, 1982), are of historical interest only; for example, freeforms are no longer tumbled in sawdust. Further, early Ammolite triplets were made with surface-collected type 2 (sheet) Ammolite; many of these early gems tended to separate along the glued layers. Santo Carbone was the 
first to correct these problems and perfect the manufacturing techniques that are now used to produce high-quality assembled gems. Today, the modern manufacturing facilities of Korite in Calgary, which employs about 20 full-time cutters (about 50 staff members total), dominate the production of Ammolite for the world market, although there are several smaller operations throughout Alberta.

Rough Ammolite that is sufficiently thick and durable for manufacture into solids goes through the following steps: slabbing; trimming; stabilizing, if necessary; grinding to optimum colors; polishing; and shaping. Note that the cutter will constantly grind a piece of Ammolite until it shows the most attractive color display; this delicate technique takes years of experience to perfect-too much grinding could destroy a good color suite and pattern. Material that is made into triplets (again, see figure 1) goes through a similar set of early steps, but after a first grinding to reach optimal colors (the Ammolite will still be relatively thick), a spinel or

TABLE 2. Grading categories of Ammolite.

\begin{tabular}{|c|c|}
\hline Grade & Description \\
\hline Extra fine & $\begin{array}{l}\text { Stone exhibits three or more sharp and brilliant } \\
\text { colors (usually red, yellow, green, and/or blue). } \\
\text { Colors are naturally bright with no obvious dark } \\
\text { areas. Show of color does not depend on orien- } \\
\text { tation. Fractures are in aesthetically pleasing pat- } \\
\text { terns and, more importantly, are narrow. Stones } \\
\text { with rare colors, specifically blue and purple, are } \\
\text { most desirable. }\end{array}$ \\
\hline Fine & $\begin{array}{l}\text { Stone exhibits at least two distinct colors. Colors } \\
\text { are not as bright as those in "Extra Fine" grade, } \\
\text { and the stone may have some dark areas. Show } \\
\text { of color does not depend on orientation. } \\
\text { Fractures may distract somewhat from the beauty } \\
\text { of the stone. }\end{array}$ \\
\hline Good & $\begin{array}{l}\text { Stone exhibits at least one distinct color or play of } \\
\text { color. Dark areas are more apparent than in } \\
\text { "Fine" grade material. The color may be direction- } \\
\text { al. Fracture patterns may be distracting. }\end{array}$ \\
\hline Fair & $\begin{array}{l}\text { Colors and color changes are less distinct than } \\
\text { "Good" grade. Colors commonly are from the } \\
\text { middle of the spectrum, i.e., yellow and green. } \\
\text { Directional color display is more apparent than in } \\
\text { "Good" grade stones. Fracture patterns may be } \\
\text { distracting. This category represents most of the } \\
\text { current production (38\%). }\end{array}$ \\
\hline Poor & $\begin{array}{l}\text { Faint colors or play of color, sometimes with a } \\
\text { brown overtone; Noticeably poor brilliance. }\end{array}$ \\
\hline Commercial & $\begin{array}{l}\text { Dark brown or gray body color with faint color } \\
\text { patches. May have unappealing fracture patterns. } \\
\text { Lowest quality; currently not offered or commer- } \\
\text { cially available from Korite although it is } \\
\text { being kept in inventory. }\end{array}$ \\
\hline
\end{tabular}
back of the gem material is ground again to reduce thickness, and a piece of shale (typically from the Bearpaw Formation) that has been coated with lampblack is attached with epoxy to form a backing. A final trimming provides calibrated sizes. Using much the same process, Korite will attach a natural shale backing to polished pieces of Ammolite that are too thin and fragile for use as solids to create doublets. For some of his assembled stones, Mr. Carbone uses two individual Ammolite layers together with the backing and the cap (forming an Ammolite "quadruplet"), which increases the quantity and intensity of colors in the finished piece (see figure 12). Barnson (2000) provides stepby-step details of the manufacturing process.

Mr. Carbone also creates a unique mosaic-like Ammolite "triplet" that has been marketed exclusively since 1997 by Aurora Canadian Jewellery as Auroralite (figure 13). These triplets have a glitter effect produced by a patented process (Carbone, 1991) in which multi-colored fragments of Ammolite $(0.5-3 \mathrm{~mm}$ wide) are attached with epoxy to a synthetic spinel or quartz cap. Air trapped in the epoxy is removed in a vacuum unit and then the cap is placed in a preheated oven to harden the epoxy to a gel-like state. At this point, grains of carborundum are sprinkled on the epoxy to form the base. Recently, Johnson et al. (2000) described these triplets, which Korite had provided for examination and were erroneously attributed to their mining operation.

In recent years, other innovative uses have been found for material that is not suited for manufacture into solids or assembled stones. For example, mosaics of small Ammolite fragments have been cemented into watch faces and other forms of jewelry.

\section{QUALITY GRADING OF AMMOLITE}

Although an internationally accepted grading system for Ammolite does not exist, Korite has developed its own in-house grading system. A number of abbreviated versions of this same system have been published (Barnson, 1996; "Gemstone unique to Canada ...," 1999; Barnson, 2000).

There are six recognized grades of Ammolite as described in table 2: Extra Fine, Fine, Good, Fair, Poor, and Commercial (which correspond to Korite's AA, A+, A, A-, B, and C). The three factors in determining the grade of a polished (unmounted) 


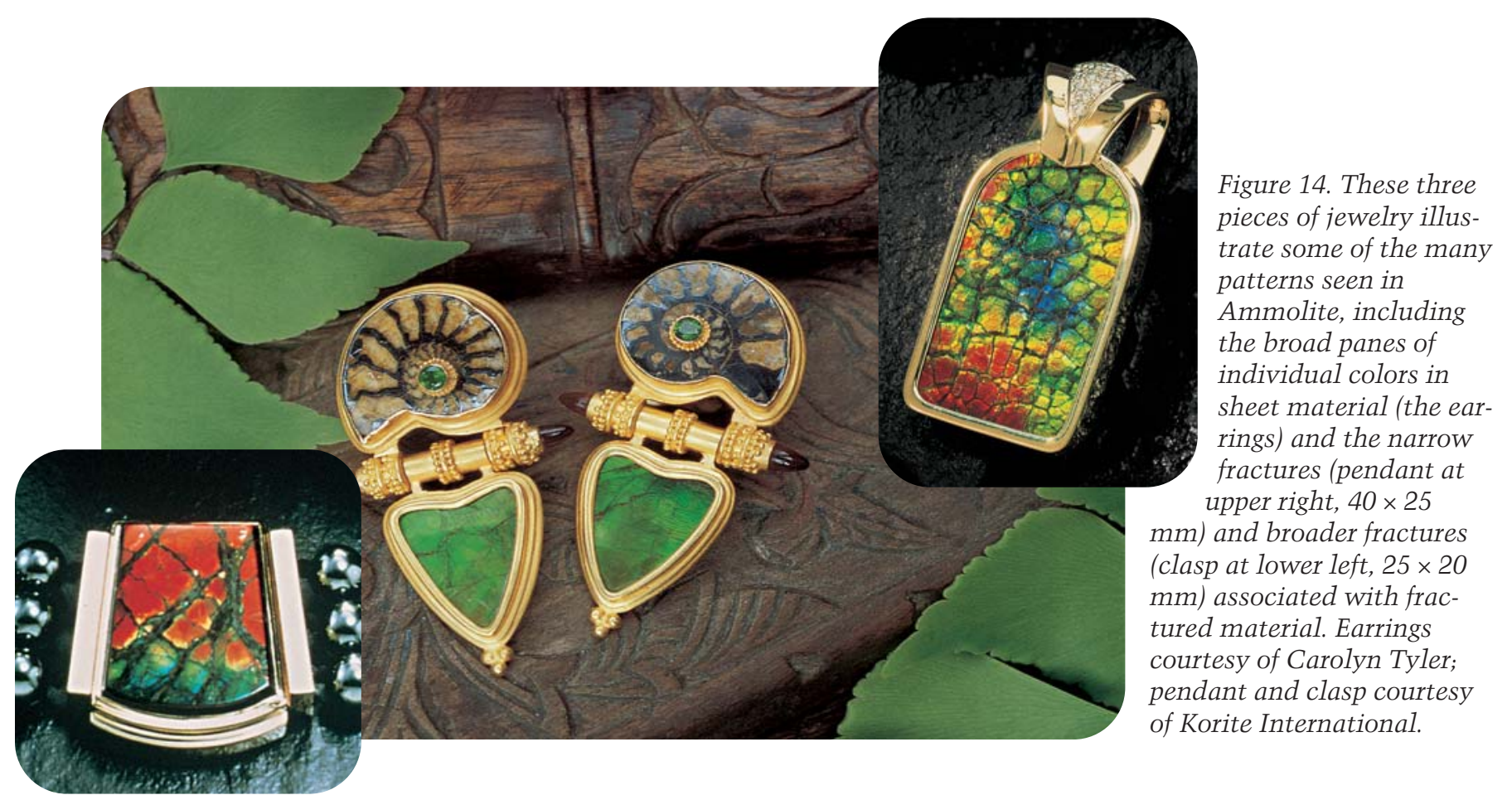

Ammolite solid or assembled stone are: color range and display, intensity of iridescence, and pattern. The grade distribution, as a percent of Korite's total sales for 2000 (P. Paré, pers. comm., 2001), was: Extra Fine-6\%, Fine-5\%, Good-21\%, Fair$38 \%$, and Poor-30\% ("Commercial" grade material was not sold).

Figure 15. Among the rarest of the patterns seen in Ammolite is this suture pattern, which mimics the internal structure of the original shell. These Ammolites (both one-sided solids) measure $4.1 \times 3.1 \mathrm{~cm}$ and $3.2 \times 2.6 \mathrm{~cm}$. Courtesy of Santo Carbone; photo (C) Harold $\oplus$ Erica Van Pelt.

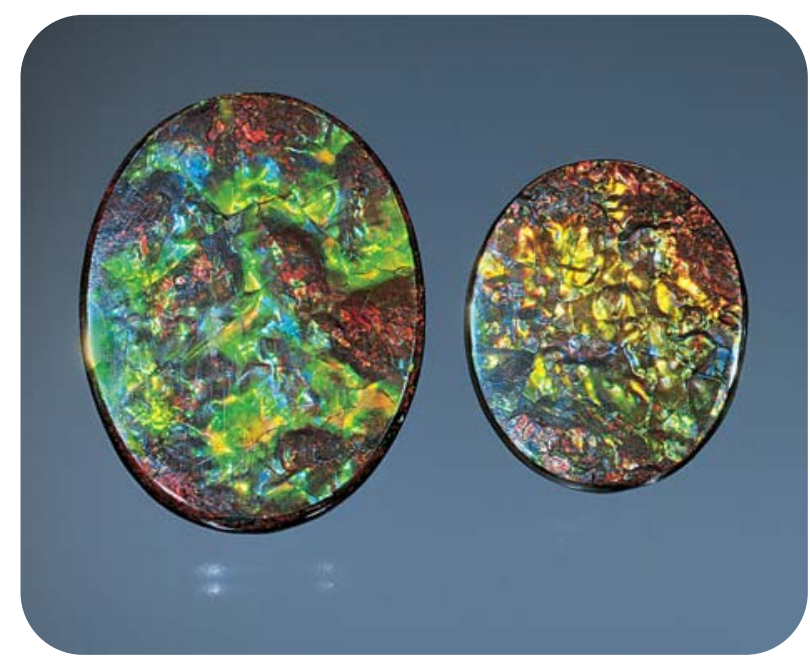

Color Range and Display. In general, the more colors displayed, the higher the grade. Thus, stones that exhibit the full color spectrum, and especially blue and violet or purple (the latter is particularly rare), are most desirable. Stones that exhibit only one color, especially entirely red or brown (which, after white, are the most common colors found on Bearpaw Formation ammonite), are less desirable.

Intensity of Iridescence. The ideal Ammolite shows sharp color sections and bright hues. Although some stones exhibit a full color spectrum, the colors may appear dark when illuminated from different directions. Such a directional display of color detracts from the beauty, and hence the value, of a stone and can generate a grade no higher than Fine.

Pattern. Pattern is the composite appearance of the color panes in relation to the dark, non-iridescent fracture system that permeates the specimen and frames them (commonly referred to as "stained glass window" effect; see figure 14 and other Ammolite photos in this article). Quality grading for pattern is usually more applicable to type 1 Ammolite. Stones with wide fractures on the surface are graded lower than stones with few or very narrow fractures. Some stones may also exhibit a "suture" pattern derived from the original shell structure (see figure 15). Although common to many types of fossil ammonites, suture patterns in finished Ammolite gems are rare. 


\section{CHARACTERIZATION OF AMMOLITE}

Materials and Methods. Korite provided samples of both rough and polished Ammolite from the Oxbow and Zone 4 mines. Every variety of Ammolite was represented: fractured (type 1) and sheet (type 2); all colors, but particularly red, green, and blue; two-sided solids, one-sided solids, doublets, and triplets in various stages of production; and stabilized and unstabilized material. In addition, we studied two concretions. In total, 93 samples were subjected to some type of analysis from among many hundreds of specimens placed at our disposal by Korite. We performed visual and microscopic observation on approximately 50 additional samples.

Samples were examined with magnification ranging from $10 \times$ to $45 \times$, usually with a GIA Gem Instruments Mark VI Gemolite microscope. Refractive indices (10 samples) were measured on a GIA Gem Instruments Duplex II refractometer with a monochromatic sodium-equivalent light source. Specific gravity (7 samples) was measured by the hydrostatic method with a Mettler H31 balance. Fluorescence (8 samples) was determined with a GIA Gem Instruments ultraviolet lamp. Thin sections-four of type 1 (fractured) and three of type 2 (sheet) material-were studied and photographed with a Zeiss Axioplan binocular polarizing microscope. Hardness (4 samples) was estimated by scratching Ammolite with calcite and fluorite.

X-ray diffraction patterns (10 samples) were obtained on a Scintag Model XDS 2000 instrument, and the data were interpreted using the Material Data Inc. "Jade XRD Processing" software package. We conducted scanning electron microscope studies with a Cambridge Stereoscan 250 instrument to determine the microstructural characteristics of Ammolite layers and their correlation with color (if any). We had 41 samples (all rough; consisting of both type 1 and type 2 Ammolite) mounted and prepared (e.g., coated with gold) "on edge" so that the horizontal layers were perpendicular to the electron beam. Only red, green, or violet/purple material was used, as these colors represent the long, intermediate, and short wavelengths of visible light as well as the range of colors found in Ammolite. An attached Kevex Micro-X 7000 Analytical Spectrometer was used for energy-dispersive elemental analysis (SEMEDX) on 6 rough samples (three of type 1 and three of type 2), which were analyzed parallel to the upper surface. Prof. G. R. Rossman obtained visible/nearinfrared spectra (2 samples) with a custom-made reflectance spectrometer.
Results. The results of our research are given in table 3 and discussed below.

Composition. The X-ray diffraction (XRD) studies confirmed that the composition of Ammolite is essentially pure aragonite; organic matter, which is undoubtedly present (see below, Mineralogy of Ammolite) is not detected by this technique. Only calcium was detected (by SEM-EDX) on the iridescent Ammolite surfaces, except for trace amounts of strontium and iron.

The material that comprises the non-iridescent

TABLE 3. Properties of Ammolite.

\begin{tabular}{|c|c|}
\hline Property & Description \\
\hline Mineral name & Aragonite \\
\hline Composition & $\mathrm{CaCO}_{3}$ \\
\hline Crystal system & Orthorhombic \\
\hline Morphology (of rough) & $\begin{array}{l}\text { Type } 1 \text { (fractured): Flat iridescent layers } \\
\text { are fractured and the fractures are } \\
\text { healed with non-iridescent material, } \\
\text { resulting in a mosaic texture } \\
\text { Type } 2 \text { (sheet): Flat areas have no frac- } \\
\text { tures and no special features (except } \\
\text { rare suture patterns) } \\
\text { Thickness of layers rarely exceeds } 8 \mathrm{~mm}\end{array}$ \\
\hline Iridescent color & $\begin{array}{l}\text { All colors, with red and green most } \\
\text { abundant; blue is rare and purple } \\
\text { extremely rare }\end{array}$ \\
\hline Clarity & $\begin{array}{l}\text { Normally opaque; transparent or trans- } \\
\text { lucent in very thin sheets }\end{array}$ \\
\hline Luster & Vitreous to resinous \\
\hline Hardness & 3.5 \\
\hline Toughness & $\begin{array}{l}\text { Red Ammolite is relatively tough, but } \\
\text { blue and purple are brittle }\end{array}$ \\
\hline Refractive indices & $\begin{array}{l}\text { Low values: } 1.525-1.530 \\
\text { High values: } 1.665-1.670\end{array}$ \\
\hline Birefringence & $0.135-0.145$ \\
\hline Specific gravity & $2.76-2.84$ \\
\hline UV fluorescence & $\begin{array}{l}\text { Iridescent material inert to both long- } \\
\text { and short-wave UV; non-iridescent } \\
\text { healed fracture material has weak yellow } \\
\text { fluorescence, stronger to long-wave UV }\end{array}$ \\
\hline Parting & $\begin{array}{l}\text { Parting along flat layers most common } \\
\text { in rough type } 2 \text { Ammolite }\end{array}$ \\
\hline Inclusions & $\begin{array}{l}\text { Pyrite, organic matter; these only occur } \\
\text { between Ammolite layers and cannot be } \\
\text { seen from the surface of polished stones }\end{array}$ \\
\hline Durability & $\begin{array}{l}\text { Solids should be handled carefully } \\
\text { because of softness and susceptibility to } \\
\text { chemicals, household products, and } \\
\text { excessive heat; triplets (with quartz or } \\
\text { synthetic spinel caps) are stable under } \\
\text { normal conditions }\end{array}$ \\
\hline May be confused with & $\begin{array}{l}\text { Opal, fire agate, labradorite, and various } \\
\text { modern (e.g., abalone) or other fos- } \\
\text { silized (e.g., lumachelle) shell materials }\end{array}$ \\
\hline
\end{tabular}


healed fractures is also predominantly aragonite (as reported by Wight, 1981), but calcite was the main filler in some of the fractures. In addition, S. Carbone (pers. comm., 2000) has identified clay minerals (species unidentified) in some fractures, and this is consistent with our detection by SEM-EDX of Al and $\mathrm{Si}$ (the main chemical components of clays) during qualitative analysis of several fracture fillings.

XRD analysis of the host concretions showed that they contain siderite $\left(\mathrm{FeCO}_{3}\right)$, which is in agreement with Niedermayr (1999).

Visual Appearance. In the rough, type 1 (fractured) Ammolite ideally appears as a collage of vivid iridescent colors (all colors of the spectrum, with red and green the most abundant), separated by healed fractures. However, the number and quality of the colors can vary over short distances (e.g., a few millimeters). Type 2 (sheet) Ammolite, on the other hand, usually has two predominant spectral colors, which vary by the piece (color panes up to several centimeters are common). Although the iridescent areas in both types are generally less than $20 \mathrm{~cm}(\sim 8$ inches) in maximum dimension, only much smaller areas, particularly in the type 1 variety, will have uniform color, quality, or thickness. The Ammolite layers, which are supported on shale or concretionary material, may vary in thickness from about $8 \mathrm{~mm}$ to film-like in the same sample.

Data supplied by Korite, and verified by the authors, for fashioned material indicate that an average Ammolite triplet will consist of a 0.1-mm-thick Ammolite layer with a 1-mm-thick shale backing and a $1.5-\mathrm{mm}$-thick synthetic spinel cap, weigh a total of $2.5 \mathrm{ct}$, and measure $11 \times 9 \mathrm{~mm}$ (oval). Average doublets have a 1-mm-thick Ammolite layer with a 2.5 -mm-thick shale backing, weigh 18 ct, and measure $29.5 \times 28.5 \mathrm{~mm}$. An average onesided solid also consists of a 1-mm-thick Ammolite layer, which is naturally attached to a $2.5-\mathrm{mm}$-thick shale matrix; it weighs 17 ct and measures $29 \times 28$ $\mathrm{mm}$. Average two-sided Ammolite solids are typically $3 \mathrm{~mm}$ thick, weigh $15 \mathrm{ct}$, and measure $28 \times 24$ $\mathrm{mm}$. In general, stabilized Ammolite solids and doublets are larger than their unstabilized counterparts and can range up to $50 \mathrm{~mm}$ (and, rarely, as large as $100 \mathrm{~mm}$ ) in longest dimension.

Diaphaneity and Luster. Ammolite is transparent or translucent to transmitted light only in extremely thin sheets, such as those used for assembled stones. Because these always have a dark backing, however, the material seen in jewelry (including one- and twosided solids) is opaque. Luster ranges from vitreous to resinous, and the intensity may vary considerably between samples, from very dull to intense.

Hardness. The Mohs hardness of Ammolite is 3.5; it can be scratched by fluorite $(\mathrm{H}=4)$ but not by calcite $(\mathrm{H}=3)$.

Refractive Indices and Birefringence. We recorded R.I. values for 10 polished stones, five each of type 1 (fractured) and type 2 (sheet). Five were red, four were green, and one was blue. The low values ranged from 1.525 to 1.530 , and the high values measured were 1.665-1.670. We found no relationship between color and R.I. Birefringence was 0.140-0.145 in eight of the 10 samples; for two green samples-one of each type-the birefringence was 0.135 , but we are unable to attach any significance to this difference. These data are very similar to those reported by Wight (1981).

Specific Gravity. The seven samples selected for S.G. determinations were all double-sided solids and predominantly red (purposely chosen to minimize any possible variance related to color). The S.G. of the four type 1 (fractured) Ammolites ranged from 2.81 to 2.84 . The values obtained for the three type 2 (sheet) Ammolites averaged 2.76, 2.76, and 2.84. Wight (1981) determined the S.G. for Ammolite (type 1 from the now-closed Kormos mine; number of samples studied not stated) to be $2.80 \pm 0.01$. The S.G. of pure aragonite is 2.94 (Gem Reference Guide, 1995). The lower values presented here for type 1 Ammolite can be explained by the presence within Ammolite of small amounts of organic matter and calcite, which have lower S.G.'s; in type 2 Ammolite, voids between the layers also contribute to a lower S.G. Inclusions of pyrite (S.G. about 5), discussed below, will increase the overall S.G. of the Ammolite.

Fluorescence. Yellow ultraviolet fluorescence (longwave stronger than short-wave) was observed only in the material healing the non-iridescent fractures of type 1 Ammolite. Whereas Wight (1981) describes this fluorescence as bright or intense, we classify it as weak.

Parting. All Ammolite may part into sheet-like layers, although type 2 Ammolite is more susceptible. Cleavage was not observed. 

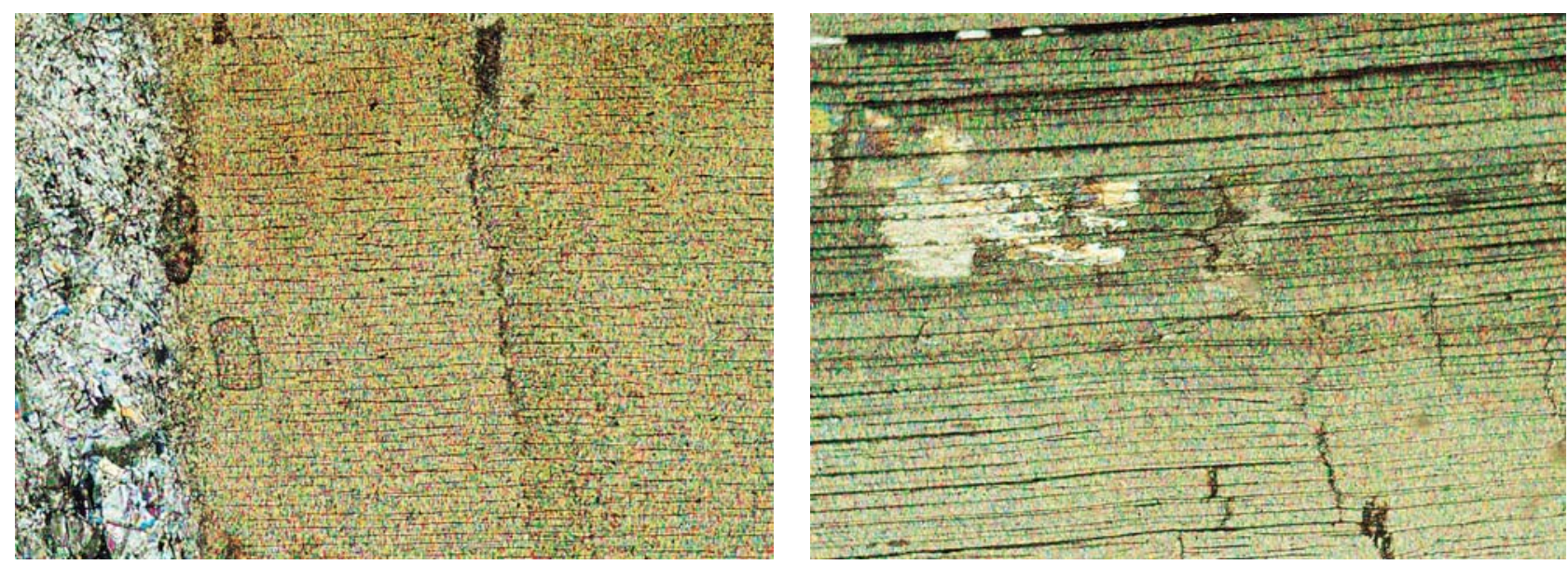

Figure 16. These two thin sections of ammolite (type 1 from the K Zone on the left and type 2 from Zone 4 on the right) were photographed in polarized light perpendicular to the flat surface (parallel to the edge) of each stone. Thin, prismatic crystals of aragonite are seen in both types of Ammolite. In the type 1 material, however, they are in laminae (layers) of limited extent arranged with a shingle effect; fractures are abundant (one is seen here on the left side of the photo cutting across the laminae at right angles) and are filled with coarse secondary aragonite and sometimes calcite and clays. The aragonite layers in type 2 Ammolite are essentially continuous; they are not interrupted by fractures. The relatively thick dark layer at the top of this photo contains organic matter (black) as well as minute disseminated pyrite grains (not visible). The shell layer in both samples is 2-3 mm thick. The width of each photomicrograph represents $2.3 \mathrm{~mm}$.

Inclusions. Zeitner (1978), Koivula (1987), and Wight (1993) have reported pyrite blebs in finished Ammolite. We also identified pyrite, by XRD analysis. This was seen in small amounts in thin sections as an opaque, highly reflective, yellowish mineral that occurred as blebs or comprised very thin layers within the Ammolite. Both pyrite and organic matter (see Mineralogy of Ammolite below) occur between Ammolite layers and cannot be seen from the surface of polished stones. Stafford (1973b) and Sinkankas (1976) reported the occurrence of hydrocarbons in finished Ammolite; however this "inclusion" was artificial, in that it had been introduced by the oil-lubricated saws used to cut the earliest Ammolites.

Other Microscopic Studies. Thin sections (microscopic studies) of the nacreous layers from type 1 (from the K Zone) and type 2 (from Zone 4) Ammolites are shown in figure 16. In both cases, the microstructure shows fine laminae (layers) of prismatic aragonite crystals. In the type 1 specimen, however, these laminae are of limited lateral extent and exhibit a "shingle" structure; in addition, a natural fracture-healing material (aragonite, calcite and/or clay minerals) is evident. In the type 2 specimen illustrated, the laminae are much more continuous and are not cross-cut with fracture fillings. We believe that the material that fills fractures, and the shingle structure in the type 1 material, jointly act as a "structural support" for the aragonite laminae, so that this material can be used in jewelry without stabilization. As noted above, type 2 material lacks this structural support and may have to be polymerimpregnated before it can be manufactured into jewelry.

Scanning electron microscopy revealed additional details of the nacreous layer. As figure 17 illustrates, red Ammolite is composed of stacked columns of aragonite tablets. The aragonite tablets in green Ammolite are thinner and occur in a less organized vertical arrangement. Purple Ammolite has even thinner tablets, which show no stacking arrangement.

Discussion. Mineralogy of Ammolite. Shell microstructure studies of the modern Nautilus, fossil ammonites, and specimens from many other Mollusca (Wise, 1970; Grégoire, 1987; Dauphin and Denis, 1999) have shown that they are all composed of layers of aragonite crystals with small amounts of organic material (usually between 0.01 and 5 wt.\%; Lowenstam and Weiner, 1989). This combination of thin tablets of aragonite interleaved with much thinner sheets of organic matter, frequently with a mother-of-pearl luster, is known as nacre (Jackson, 1997). Using SEM imaging, Dauphin and Denis (1999) established that the shells of living Nautili have three layers, each of which is characterized by 

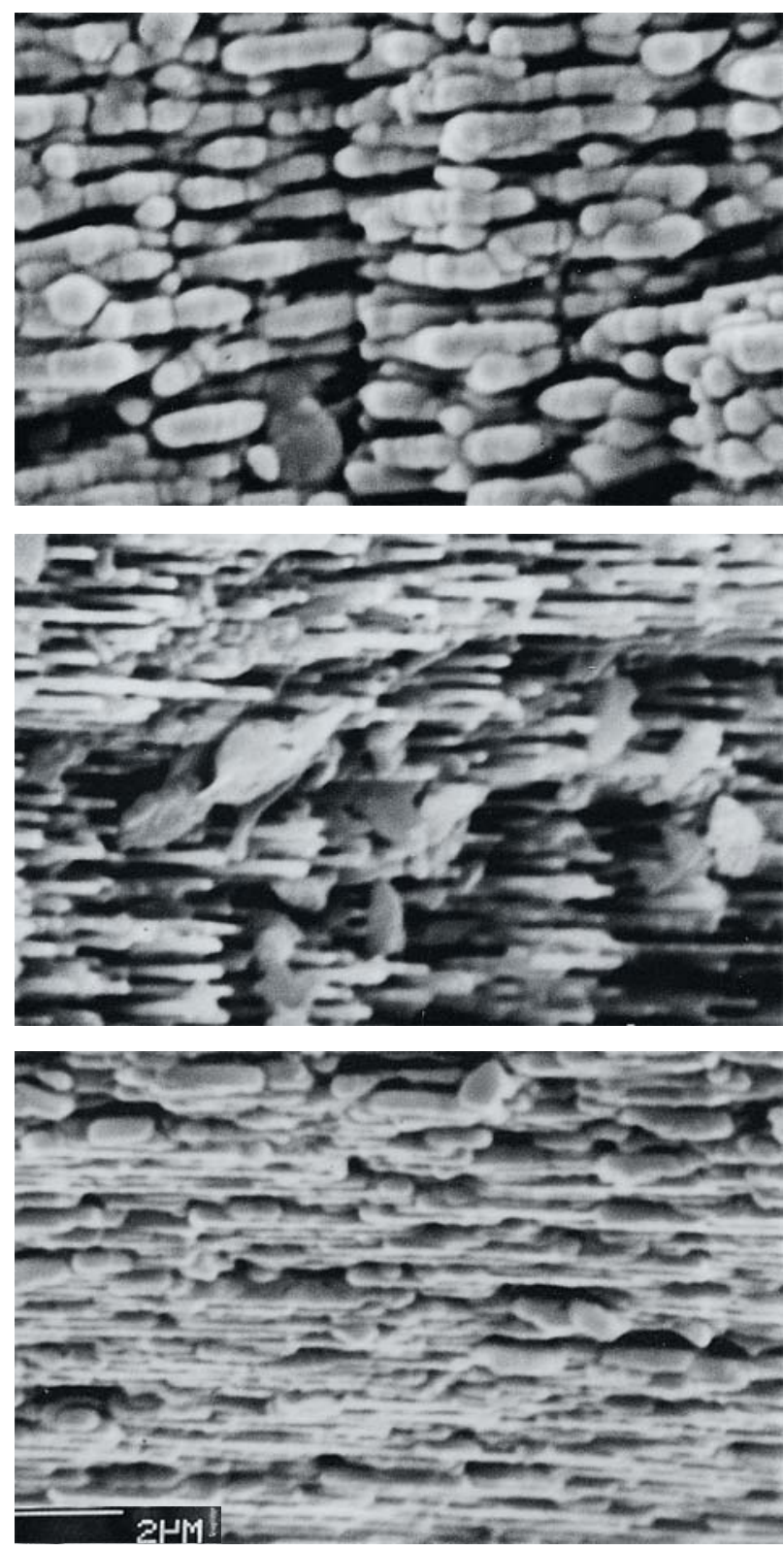

Figure 17. Distinct differences in the arrangements, sizes, and shapes of the aragonite crystals in Ammolite can be seen in the scanning electron micrographs of these representative red (top), green (center), and purple (bottom) samples. Scale bar is 2 microns.

different shapes and arrangements of crystals: (1) an outer spherulitic-prismatic layer; (2) a middle, thicker, nacreous layer; and (3) an inner, thin prismatic layer. Fossilized ammonite shells usually have only the nacreous layer preserved.

That ammonite shells were originally composed of aragonite has been known since the late 1800s (reviewed by Grégoire, 1987; Lowenstam and Weiner, 1989). We have confirmed that Ammolite is also composed of aragonite, in agreement with Wight (1981). Lowenstam and Weiner (1989) noted that the oldest known sedimentary deposit with abundant aragonite fossils dates from the Carboniferous Period (about 340 million years ago); the ammonites from which Ammolite is derived lived between 75 and 70 million years ago (see Geology and Occurrence section above).

The Microstructure of Ammolite and Its Correlation with Color. In addition to the differences in thickness and organization of the aragonite tablets noted with SEM for the different colors of Ammolite, we have also observed that Ammolites of different colors have different physical attributes, which we suggest are related to their unique microstructures. Red Ammolite is stronger (tougher, easier to manufacture into gemstones) than green Ammolite, while purple Ammolite is the weakest of all. Further, cutters (e.g., S. Carbone, pers. comm., 2000) have observed (qualitatively) that the hardness of Ammolite, at least in polishing, varies with color and decreases in the order red-green-purple. We suggest that this is another manifestation of the microstructure differences of the various colored Ammolites illustrated in figure 17. If this is the case, a corollary might be that the rarity of purple and blue Ammolite can be explained by the fact that the microstructures responsible for these colors are less likely to have survived in the natural environment due to their relative weakness.

Cause of Color in Ammolite. Several explanations have been proposed for the cause of the iridescent color of Ammolite. All the explanations fall into two basic categories: interference (Pough, 1986; Fritsch and Rossman, 1988; Vandervelde, 1993; Niedermayr and Oehner, 1995; Niedermayr, 1999), or diffraction (Leiper, 1969; Wight, 1981; Brown, 1984; Vandervelde, 1991). However, none of the above references offered experimental work to confirm either explanation. Although both interference and diffraction can produce color in minerals when white light interacts in certain ways within a specimen, the mechanism of the reaction, and its result, will be specific for each phenomenon (for more on these mechanisms, see Fritsch and Rossman, 1988, pp. 86-89).

The visible/near-infrared reflectance spectrum obtained from a piece of type 2 (sheet) Ammolite 
from Zone 4 (illuminated with white light) indicates that light reflected from the yellow-green portion of the shell is more intense in a band that is centered at about $568 \mathrm{~nm}$. This spectrum is consistent with what would be expected for an interference phenomenon, as light passes through and reflects back from multiple layers of aragonite of uniform thickness (G. R. Rossman, pers. comm., 2000). This model is confirmed by the observation of uniform layers in the electron micrograph of a section of Ammolite (again, see figure 17). The lack of an array of uniform grooves or ridges, such as is found in diffraction gratings, and the comparatively large width of the band in the reflectance spectrum (lack of a pure spectral color), argue against diffraction to explain the color in Ammolite (G. R. Rossman, pers. comm., 2000).

Tilting has the effect of changing the relative position of interfering light waves, thus producing a different color in most Ammolites (this is the same as directional color mentioned in the Quality Grading section). When a piece of predominantly red Ammolite is tilted, the colors change in the sequence orange, yellow, and green. When a piece of predominantly green Ammolite is tilted, blue may be obtained. There is almost no change of color when a piece of purple or blue Ammolite is tilted.

In addition, as noted above, the color of Ammolite can be shown to depend, at least to some extent, on the amount of polishing, which affects the final thickness of the nacre. Thus, if the original color of a piece of Ammolite is blue, polishing exactly parallel to the surface will change the color in the following sequence: blue-green-yellow-orange-red (see figure 7; also, P. Paré and S. Carbone, pers. comms., 2000). This corresponds to the changes shown in figure 17, and the final color will be related to the structural characteristics (including both thickness and stacking arrangement) of the nacreous layer on the surface of the polished stone.

\section{CARE AND DURABILITY}

Ammolite is used in all forms of jewelry. Because it is soft and will scratch easily, solid Ammolite is best suited for brooches, pendants, or earrings rather than rings. Since Ammolite, like pearls, is delicate and consists of aragonite, many of the care and cleaning recommendations for pearls also apply to Ammolite. Ultrasonic and steam cleaners should never be used for solids; rather, a commercial pearl cleaner or a mild, warm soap solution is recommended (a maxi- mum of 20 minutes in any fluid). Contact with heat, acids, perfumes, hairsprays, and many household commodities can cause loss of iridescence and other types of damage, particularly in solids.

Triplets with properly manufactured synthetic spinel or quartz caps may be cleaned, with caution, in ultrasonic cleaners. Warm soap and other mild solutions may also be used, again with caution. Although the cap will protect the Ammolite from scratches, care should be taken to avoid blows that could result in the separation of glued layers.

\section{CONCLUSION}

Ammolite is vivid iridescent fossilized ammonite shell (aragonite) that thus far has been obtained from only two ammonite species (Placenticeras meeki and $P$. intercalare), and only from those found in the Bearpaw Formation of southern Alberta, Canada. However, to be marketable as a gemstone, the Ammolite layers must not only show attractive color and pattern, but they must also be sufficiently thick and durable to withstand use in jewelry. Because of these durability concerns, most of the Ammolite currently in the marketplace is found as assembled stones (triplets consisting of a synthetic spinel or quartz cap, a layer of Ammolite, and a shale backing). Stabilization (with polymers) is also used on some Ammolite solids and doublets.

We believe the formation of Ammolite is directly related to depth of burial of the original ammonite. Hence, Ammolite exploration should be focused on areas where the Bearpaw Formation has been buried to optimum depth $14 \mathrm{~km}$ in the St. Mary River area) and re-exposed due to uplift and erosion. Delineation of commercial deposits of Ammolite, however, has proved difficult (in fact, the commercial operation described in Voynick [1993] no longer exists). To date, only two horizons within the Bearpaw Formation of southern Alberta support open-pit mining, and attempts to trace them out laterally within the formation have been unsuccessful. As such, assuming current economic conditions, Korite has estimated a 15-year mine life for both the Kormos (when reactivated) and Oxbow mines (P. Paré, pers. comm., 2000). However, Reiskind (1975) did establish that some concretionary layers within the Bearpaw Formation cover an enormous area; if this is the case, future discoveries may be sizable.

For the first two decades after its introduction in the early 1960s, Ammolite languished as a gem 
material primarily because of the limited supply of durable rough, the lack of uniform marketing (e.g., a multitude of trade names), and the inconsistent quality of the assembled stones. In the past two decades, as a result of the development of new mines and improved manufacturing tech-

\section{ABOUT THE AUTHORS}

Mr. Mychaluk is a professional geologist in Calgary, Alberta, Canada. Dr. Levinson (levinson@geo.ucalgary.ca) and Dr. Hall are professor emeritus and associate professor, respectively, in the Department of Geology and Geophysics, University of Calgary.

Acknowledgments: The authors thank Pierre Paré, president of Korite International Ltd., Calgary, Alberta, for supplying research specimens, unpublished data, permission to visit the Korite manufacturing facilities in Calgary, and access to the niques for assembled stones and stabilizing material that delaminated, Ammolite has gained recognition worldwide. With a steady future supply, and wide versatility in today's jewelry designs, we are confident that Ammolite will continue to grow in popularity.

\section{REFERENCES}

Ammolite. New gems from old fossils (1984) Southern Jeweler, Vol. 59, No. 9, pp. 25, 31.

Barnson D. (1996) Ammolite. Privately published by Donna L. Barnson, Selkirk, Manitoba, Canada, 24 pp.

Barnson D. (2000) Ammolite 2. A Guide for Gemmologists, Jewellers and Lapidaries. Privately published by Donna L. Barnson, Selkirk, Manitoba, Canada, 116 pp.

Boyd W.F., Wight W. (1983) Gemstones of Canada. Journal of Gemmology, Vol. 8, No. 6, pp. 544-562.

Brown G. (1984) Korite -A unique organic gem. Australian Gemmologist, Vol. 15, No. 6, pp. 206-208.

Carbone S. (1991) Composite Gem Stone and Production Method. Canadian Patent 1281871, issued March 26, 1991; U.S. Patent 5,015,499, issued May 14, 1991.

Crowningshield R. (1977) A new jewelry item. Gems «) Gemology, Vol. 15, No. 10, p. 312.

Dauphin Y., Denis A. (1999) Diagenèse compareé des phases minérales et organiques solubles dans les tests aragonitiques de nautiles et d'ammonites. Bulletin de la Société Géologique de France, Vol. 170, No. 3, pp. 355-365.

Dick G. (1991) Short in supply, long in beauty. American Jewelry Manufacturer, Vol. 39, No. 7, pp. 34-35.

Dowling D.B. (1917) The Southern Plains of Alberta. Geological Survey of Canada, Memoir 93.

England T.D.J., Bustin R.M. (1986) Thermal maturation of the Western Canadian Sedimentary Basin south of the Red Deer River: I) Alberta Plains. Bulletin of Canadian Petroleum Geology, Vol. 34, No. 1, pp. 71-90.

Fritsch E., Rossman G.R. (1988) An update on color in gems, Part 3: Colors caused by band gaps and physical phenomena. Gems «) Gemology, Vol. 24, No. 2, pp. 81-102.

Gem Reference Guide (1995) Gemological Institute of America, Santa Monica, CA, $270 \mathrm{pp}$

Gemstone unique to Canada making waves (1999) Jewellery News Asia, No. 176, pp. 62, 64.

Grégoire C. (1987) Ultrastructure of the Nautilus shell. In W.B. Saunders and N.H. Landman, Eds., Nautilus-The Biology

Kormos and Oxbow Ammolite mines near Lethbridge. Santo Carbone of Calgary kindly reviewed this article and provided unpublished data and samples. Professor G. R. Rossman of the California Institute of Technology kindly supplied the reflectance spectrum and discussed with us the origin of color in Ammolite. D. Glatiotis and M. Glatiotis, Department of Geology and Geophysics, University of Calgary, are thanked for taking scanning electron micrographs and for X-ray diffraction patterns. Thanks also to Barnson Photography of Selkirk, Manitoba, and Aurora Canadian Jewellery of Calgary for providing photographs. Discussions with Allan Ingelson of Calgary and Paul Evanson of Edmonton were very informative. and Paleobiology of a Living Fossil. Plenum Press, New York, pp. 463-486.

Gübelin E. (1980) Ammolith. Ein neuer fossiler Schmuckstein. Lapis, Vol. 5, No. 4, pp. 19-24 (in German).

Hadley W.D. (1981a) "Korite"-Here are more details of this amazing "new" gemstone. Rock Æ Gem, Vol. 11, No. 4, pp. 60-61.

Hadley W.D. (1981b) "Korite"-A new gemstone that's 70 million years old. Rock et Gem, Vol. 11, No. 3, pp. 44-46.

Hatcher J.B., Stanton T.W. (1903) The stratigraphic position of the Judith River beds and their correlation with Belly River beds. Science, Vol. 18, No. 5, pp. 211-212.

Hembroff W.V. (1998) Action No. 9806-00404, Court of Queen's Bench of Alberta, Judicial District of Lethbridge/Macleod, July 16.

Jackson J.A. (1997) Glossary of Geology, 4th ed. American Geological Institute, Alexandria, VA, 769 pp.

Jarand W.H. (1982) Processing ammonite shell. Lapidary Journal, Vol. 36, No. 5, p. 948.

Johnson M.L., Koivula J.I., McClure S.F., DeGhionno D., Eds. (2000) Gem news: Mosaic ammonite. Gems ↔) Gemology, Vol. 36, No. 3, pp. 261-262.

Koivula J.I. (1987) Pyrite in Canadian ammonite. Australian Gemmologist, Vol. 16, No. 8, pp. 304-307.

Koivula J.I., Kammerling R.C. (1991) Plastic-treated Ammolite. Gems $\nrightarrow$ Gemology, Vol. 27, No. 1, p. 52.

Kraus P.D. (1982) Korite from Alberta, Canada. Lapidary Journal, Vol. 35, No. 10, pp. 1994, 1996.

Leiper H. (1969) A new fossil gem is found in Alberta, Canada. Lapidary Journal, Vol. 23, No. 7, pp. 932, 937. Reprinted in Lapidary Journal, Vol. 51, No. 4, 1997, p. 39.

Link T.A., Childerhose A.J. (1931) Bearpaw shale and contiguous formations in Lethbridge area, Alberta. Bulletin of the American Association of Petroleum Geologists, Vol. 15, Part 2, pp. 1227-1242.

Lowenstam H.A., Weiner S. (1989) On Biomineralization. Oxford University Press, Oxford, $324 \mathrm{pp}$.

Mossop G.D., Shetsen I., compilers (1994) Geological Atlas of the Western Canada Sedimentary Basin. Published jointly by the Canadian Society of Petroleum Geologists and Alberta 
Research Council, Calgary, Alberta, 510 pp.

Niedermayr G. (1994) The Bleiberg box. Lapidary Journal, Vol. 48 , No. 6, pp. 37-40, 42.

Niedermayr G. (1999) Der Schmuckstein aus der Schale. Ammolite. In R. Bode, J. Keilmann, W. Lieber, and G. Schairer, Eds., Von Ammoniten und Zwillingen, Mineralientage München Messethemenheft '99 Aussstellerverzeichnis, pp. 162-168.

Niedermayr G., Oehner K. (1995) Ammolite, ein organischer Schmuckstein aus Alberta, Kanada. Mineralien-Welt, Vol. 6, No. 6, pp. 41-46.

Organic Alberta gemstone posed numerous mining problems (1985) Canadian Mining Journal, Vol. 106, No. 4, p. 11.

Pough F.H. (1986) Ammolite-Grandmother-of-pearl. Lapidary Journal, Vol. 39, No. 10, pp. 35-41.

Reiskind J. (1975) Marine concretionary faunas of the uppermost Bearpaw Shale (Maestrichtian) in eastern Montana and southwestern Saskatchewan. In W.G.E. Caldwell, Ed., The Cretaceous System in the Western Interior of North America, Geological Association of Canada Special Paper No. 13, pp. 235-252.

Sinkankas J. (1976) Gemstones of North America, Vol. II. Van Nostrand Reinhold, New York, 494 pp.

Sinkankas J. (1997) Gemstones of North America, Vol. III. Geoscience Press, Tucson, AZ, 527 pp.

Stafford P. (1973a) Ammonites and baculites in southern Alberta (part 1). Gems and Minerals, No. 424, pp. 32-34.

Stafford P. (1973b) Ammonites and baculites in southern Alberta (part 2). Gems and Minerals, No. 425, pp. 27, 42-44.

Stafford P. (1973c) Ammonites and baculites in southern Alberta (part 3). Gems and Minerals, No. 426, pp. 30, 31, 41-43.
Tsujita C.J., Westermann G.E.G. (1998) Ammonoid habitats and habits in the Western Interior Seaway: A case study from the Upper Cretaceous Bearpaw Formation of southern Alberta, Canada. Palaeogeography, Palaeoclimatology, Palaeoecology, Vol. 144, Nos. 1-2, pp. 135-160.

Vandervelde R. (1991) Ammolite, an organic gemstone from Alberta. In Z.D. Hora, W.N. Hamilton, B. Grant, and P.D. Kelly, Eds., Industrial Minerals of Alberta and British Columbia, Canada, British Columbia Geological Survey, Open File 1991-23; and Alberta Geological Survey Information Series 115, pp. 171-172.

Vandervelde R. (1993) Ammolite, an organic gemstone from Alberta. Canadian Gemmologist, Vol. 14, No. 2, pp. 53-57.

Voynick S. (1993) Gem ammonite comes of age. Rock «) Gem, Vol. 23, No. 3, pp. 50, 53-54.

Ward G., Vandervelde R., Paré P. (1982) Macro-Paleo Bearpaw Formation, Southern Alberta. Trip No. 11, Field Trip Guidebook, Canadian Society of Petroleum Geologists.

Wight Q. (1993) Canadian Ammolite-The high, dry sea floor yields opal-like material. Rock «) Gem, Vol. 23, No. 12, pp. $42,43,45-47$.

Wight W. (1981) "Korite"-Fossil ammonite shell from Alberta, Canada. Journal of Gemmology, Vol. 17, No. 6, pp. 406-415.

Wight W. (1995) Canadian gemstones: Old \& new. Canadian Gemmologist, Vol. 16, No. 3, pp. 82-87.

Wise S.W. (1970) Microarchitecture and mode of formation of nacre (mother-of-pearl) in pelecypods, gastropods, and cephalopods. Eclogae Geologicae Helvetiae, Vol. 63, No. 3, pp. 775-797.

Zeitner J.C. (1978) Calcentine is Ammolite is nacre. Lapidary Journal, Vol. 32, No. 2, pp. 622-628.

\section{MANUSCRIPT REVIEWERS}

Gems ef Gemology requires that all articles undergo a peer review process in which each manuscript is reviewed by at least three experts in the field. This process is vital to the accuracy and readability of the published article, but it is also time-consuming for the reviewer. Because members of our Editorial Review Board cannot have expertise in every area, we sometimes call on others in our community to share their intellect and insight. In addition to the members of our Editorial Review Board, we extend a heartfelt thanks to the following individuals who reviewed manuscripts for $G \oplus G$ in 2000:
Ms. Dona Dirlam
Ms. Cindy Edelstein
Mr. Israel Eliezri
Mr. Doug Fiske
Dr. Edward J. Gübelin
Ms. Gina Latendresse

\author{
Dr. G. Niedermayr \\ Dr. John Saul \\ Ms. Hedda Schupak \\ Dr. Lin G. Sutherland \\ Mr. Ron Vanderlinden \\ Dr. Christopher Welbourn
}

